\title{
Pharmacogenetics of antidepressants
}

\section{Concetta Crisafulli ${ }^{1,2}$, Chiara Fabbri ${ }^{1}$, Stefano Porcelli ${ }^{1}$, Antonio Drago ${ }^{1}$, Edoardo Spina ${ }^{3,4}{ }^{*}$, Diana De Ronchi $^{1}$ and Alessandro Serretti ${ }^{1}$}

1 Institute of Psychiatry, University of Bologna, Bologna, Italy

2 Department of Biomorphology and Biotechnologies, Division of Biology and Genetics, Polyclinic University of Messina, Messina, Italy

${ }^{3}$ Department of Clinical and Experimental Medicine and Pharmacology, University of Messina, Messina, Italy

4 Istituto di Ricovero e Cura a Carattere Scientifico Centro Neurolesi "Bonino-Pulejo," Messina, Italy

\section{Edited by:}

Kathrin Klein, Dr. Margarete

Fischer-Bosch-Institute of Clinical

Pharmacology, Germany

\section{Reviewed by:}

Chin Eap, University of Lausanne

Medical School, Switzerland

Akihito Suzuki, Yamagata University

School of Medicine, Japan

*Correspondence:

Edoardo Spina, Section of

Pharmacology, Department of Clinical

and Experimental Medicine and

Pharmacology, University of Messina,

Policlinico Universitario di Messina, Via

Consolare Valeria, 98125 Messina

Italy.

e-mail: espina@unime.it
Up to $60 \%$ of depressed patients do not respond completely to antidepressants (ADs) and up to $30 \%$ do not respond at all. Genetic factors contribute for about $50 \%$ of the AD response. During the recent years the possible influence of a set of candidate genes as genetic predictors of $A D$ response efficacy was investigated by us and others. They include the cytochrome P450 superfamily, the P-glycoprotein (ABCB1), the tryptophan hydroxylase, the catechol-Omethyltransferase, the monoamine oxidase $A$, the serotonin transporter (5-HTTLPR), the norepinephrine transporter, the dopamine transporter, variants in the 5-hydroxytryptamine receptors (5-HT1A, 5-HT2A, 5-HT3A, 5-HT3B, and 5-HT6), adrenoreceptor beta-1 and alpha-2, the dopamine receptors (D2), the $\mathrm{G}$ protein beta 3 subunit, the corticotropin releasing hormone receptors (CRHR1 and CRHR2), the glucocorticoid receptors, the c-AMP response-element binding, and the brain-derived neurotrophic factor. Marginal associations were reported for angiotensin I converting enzyme, circadian locomotor output cycles kaput protein, glutamatergic system, nitric oxide synthase, and interleukin 1-beta gene. In conclusion, gene variants seem to influence human behavior, liability to disorders and treatment response. Nonetheless, gene $\times$ environment interactions have been hypothesized to modulate several of these effects.

Keywords: pharmacogenetics, antidepressants, gene, SNP, depression

\section{INTRODUCTION}

Depressive disorders constitute a major public health issue and have been estimated to be the fourth major cause of disability worldwide, and may become second only to cardiovascular diseases in the next two decades (Mathers et al., 2000), thus contributing heavily to the global burden of diseases in man, according to Murray and Lopez (1997), who conducted a study for the World Health Organization (WHO). Unfortunately, depressed patients are not totally satisfied with the current effectiveness and tolerance of available antidepressant (AD) medications. Less than $50 \%$ of all patients treated with the currently available ADs show full remission and despite the clear need for better therapies, recent efforts to develop novel ADs have been relatively unsuccessful (Agid et al., 2007). The recent Sequenced Treatment Alternatives to Relieve Depression $\left(S T A R^{\star} D\right.$ ) trial showed that even with systematic measurement-based treatment, approximately one-third of patients reach full remission after one treatment trial, with only two-thirds reaching remission after four treatment trials. Treatment-resistant depression (TRD) is therefore a common problem in the treatment of major depressive disorder (MDD), with $60-70 \%$ of all patients meeting the criteria for TRD (Rush et al., 2006a,b; Trivedi et al., 2006a,b). It becomes of great interest to the scientific community and to our patients to report, in future clinical trials, not response rates alone but also remission rates, in order to assess the real clinical AD efficacy. This is relevant in order to improve the still incomplete knowledge of the pathogenetic mechanisms of depression and to better understand the $\mathrm{AD}$ mechanisms of action, in order to develop new $\mathrm{AD}$ drugs with a better efficacy and safety profiles. ADs currently available include first- and second-generation drugs. First-generation ADs (FGAs) include monoamine oxidase inhibitors (MAOIs) and tricyclic ADs (TCAs), which became available for therapy in the 1960s. The mechanism of MAOIs and TCAs represented the main evidence for the monoamine hypothesis of depression and major depression (MD), an intrinsically tautological hypothesis which, nevertheless, has driven pharmacological research on depression for over four decades (Blier and de Montigny, 1994; Stahl, 1998). Second-generation ADs (SGAs) include several different classes of drugs that were developed mainly in the 1980s and 1990s, starting with selective serotonin reuptake inhibitors (SSRIs) and including serotonin and noradrenaline reuptake inhibitors (SNRIs), noradrenaline reuptake inhibitors (NARIs), noradrenergic and specific serotonergic ADs (NaSSAs), and 5-hydroxytryptamine 2A (5-HT2A) receptor antagonists/reuptake inhibitors (SARIs). All the SGAs are based on the monoamine hypothesis, with a primary mechanism consisting of monoamine reuptake inhibition and/or antagonism for selected monoamine receptor(s) (Stahl, 1998). Finally, there is a class of third-generation drugs (TGAs), novel compounds that are in most cases characterized by nonmonoaminergic mechanisms (although some of these have been in development for quite a while). Most of these compounds are based on peptidergic, glutamatergic, or circadian rhythm-related mechanisms, but a few still relate to a monoaminergic mechanism (Racagni and Popoli, 2008). Nowadays one of the more promising approaches in psychiatric research is pharmacogenetics. The aim 
of pharmacogenetics is to detect genetic factors that determine variations both in clinical response and in side effects under pharmacotherapy. It is well known that the large interpatient variability in clinical response to ADs is influenced by a variety of genetic as well as pathophysiological and environmental factors. The basis for such marked interindividual variations in the clinical response to $\mathrm{AD}$ treatments is not clear yet. However it seems that at least some of this variation has a genetic basis (Serretti et al., 2005a). Increasing evidence suggests that single nucleotide polymorphisms (SNPs) can be used in clinical association studies to determine the contribution of genetic variance in drugs response (Malhotra et al., 2004; Serretti et al., 2005a; Drago et al., 2009). In recent years, the development of pharmacogenetics has provided more opportunities for individualized pharmacotherapy of depressive disorders (Perlis, 2007; Horstmann and Binder, 2009). At present time, most pharmacogenetic studies investigated genes related to metabolism, genes coding for receptors and transporters and genes related to the second messenger system (Perlis, 2007). In this review, we summarize the major findings related to the pharmacogenetics of genes affecting response to ADs. To reach this target we reviewed the literature searching the MEDLINE and EMBASE (September 2010) using the search terms pharmacokinetics, pharmacodynamics, gene, variation, $\mathrm{AD}$, efficacy, depression, mood disorder, genetic, candidate, cytochrome, P-glycoprotein (Pgp), tryptophan hydroxylase (TPH), catecholO-methyltransferase (COMT), monoamine oxidase A (MAO-A), HTT, norepinephrine transporter (NET), dopamine transporter (DAT), 5-HT1A, 5-HT2A, 5-HT3A, 5-HT3B, 5-HT6, angiotensin converting enzyme (ACE), circadian locomotor output cycles kaput protein (CLOCK), nitric oxide synthase (NOS), interleukin 1-beta (IL-1B), brain-derived neurotrophic factor (BDNF), glycogen synthase kinase 3 beta (GSK-3 $\beta$ ), adrenoreceptor beta-1 (ADRB1), adrenoreceptor alpha-2 (ADRA2A), dopamine receptors, Gbeta3, corticotropin releasing hormone $(\mathrm{CRH})$ receptor (CRHR1), glucocorticoid receptor (GR), glutamate receptor (also using extensive gene names; for overview see Table $\mathbf{1}$ ).

\section{PHARMACOKINETICS CYTOCHROME P450}

Differences in $\mathrm{AD}$ plasma concentrations, and possibly safety, may be caused by polymorphisms in the genes that encode some of the cytochrome P450 (CYP) isoenzymes that metabolize ADs. The CYP superfamily is a class of proteins containing a heme cofactor that localize mainly to the liver. They represent the major enzymes responsible for the phase I oxidative reactions of many drugs and endogenous substances and over 50 isoenzymes are known so far (Ingelman-Sundberg et al., 2007). The most relevant cytochromes in humans are: CYP1A, CYP2A6, CYP2B6, CYP2C8, CYP2C9, CYP2C19, CYP2D6, CYP2E1, and CYP3A.

The metabolic activity of CYPs is genetically determined and mutations or polymorphisms in genes coding for CYP isoforms can result in enzyme variants with higher, lower or no activity. As shown in Table 2, the isoenzymes CYP1A2, CYP2C9/19, CYP2D6, and CYP3A4 are the major enzymes that catalyze AD metabolic reactions (Spina et al., 2008).

With regards to CYP2D6 gene in particular, its polymorphisms were associated with the metabolism of most AD drugs (Lin and Lu, 1998). So far, more than 100 different alleles were reported at different frequencies in different populations of the world (for information see http://www./cypalleles.ki.se/), with a considerable number of variants which encodes inactive isoforms or with decreased or negligible activity, while other variations consist of gene duplications (Bertilsson et al., 2002). Those gene variants are often associated with different drug metabolism rate. According to the inherited CYP2D6 alleles, individuals are classified as poor (PM), intermediate (IM), extensive (EM), or ultrarapid (UM) metabolizers. Individuals who are PMs have a combination of two partially or totally defective alleles and often, they complain of side effects and drug intolerance at low dosages of drugs for its accumulation. Occasionally, these individuals are labeled as noncompliant for treatment. IMs have in their allelic combination one wild type allele plus one a partially or totally defective allele. The expected phenotype is between the EM and the PM phenotypes. In the case of CYP2D6, there is good evidence for a linear relationship between gene copy number and metabolism of a drug (i.e., amitriptyline and nortriptyline; Grasmader et al., 2004; Steimer et al., 2004). It is reasonable to expect that those drugs predominately metabolized through CYP2D6 may also show an IM status due to the low hepatic content of CYP2D6 and limiting enzymatic capacity. Drugs with additional metabolic routes (i.e., CYP2C19 and CYP3A) may have IM or EM status due to the additional metabolic routes for drug elimination. Individuals who are EM, also called normal or "wild type" have two active alleles. This genotype serves as the reference genotype for other studies. The UM category exists for CYP2D6 and CYP1A2 enzymes. UM individuals usually have multiple copies of the allele on one or the other chromosome, this condition increased enzymatic activity due to an increased the amount of protein produced (Gaikovitch et al., 2003). Interesting and noteworthy the prevalence of different genotypes and phenotypes is notably different depending on ethnicity.

Pharmacogenetic studies which investigated the influence of CYP2D6 variants on AD outcome actually do not reach univocal results; this may at least partly be due to the heterogeneity of studied populations. Indeed, while some authors reported positive association with therapeutic effects (Rau et al., 2004; Tsai et al., 2010) or side effects (Rau et al., 2004; Shams et al., 2006; Suzuki et al., 2006), other authors found lack of association (Murphy Jr. et al., 2003; Grasmader et al., 2004; Serretti et al., 2009; Murata et al., 2010), both for therapeutic and side effects (Peters et al., 2008). Moreover, several authors found an association between CYP2D6 variants and AD serum levels (Charlier et al., 2003; Grasmader et al., 2004; Suzuki et al., 2010; Tsai et al., 2010), but without univocal results (Murphy Jr. et al., 2003; Ohara et al., 2003). In the case of CYP1A2, duplications do not occur, but polymorphisms affecting transcription and translation of the encoded protein in the presence of inducers, such as tobacco smoke, can produce a UM phenotype (Sachse et al., 1999; Pavanello et al., 2005). UMs often requires doses of a CYP2D6-metabolized drug above (e.g., fluoxetine) or below (e.g., codeine, which is a prodrug for morphine) than conventional dosing guidelines to achieve a therapeutic desired effect. The CYP2C19 gene is on another cytochrome gene active in the metabolism of several ADs (Liu et al., 2002b; Yin et al., 2006; Rudberg et al., 2008; Schenk et al., 2010), and largely investigated concerning $\mathrm{AD}$ response. Also in this case the different isoforms 
Table 1 | Overview of genetic association studies.

\begin{tabular}{|c|c|c|c|c|c|c|c|c|}
\hline Gene & $\begin{array}{l}\text { Principal } \\
\text { polymorphism } \\
\text { investigated }\end{array}$ & Alleles & $\begin{array}{l}\text { Amino } \\
\text { acid } \\
\text { change }\end{array}$ & \multicolumn{2}{|c|}{ Frequency* } & Region & $\begin{array}{l}\text { Antidepressants } \\
\text { involved }\end{array}$ & Reference** \\
\hline \multirow[t]{6}{*}{ P-glycoprotein } & rs1045642 & $\begin{array}{l}\mathrm{A} / \mathrm{C} / \\
\mathrm{G} / \mathrm{T}\end{array}$ & $1145 \mathrm{l} /$ ? & A (56\%) & G (44\%) & $\begin{array}{l}\text { Coding } \\
\text { exon }\end{array}$ & $\begin{array}{l}\text { Paroxetine; } \\
\text { citalopram; } \\
\text { nortriptyline }\end{array}$ & $\begin{array}{l}\text { Roberts et al. (2002), } \\
\text { Gex-Fabry et al. (2008), } \\
\text { Kato et al. (2008a), } \\
\text { Mihaljevic Peles et al. } \\
\text { (2008), Nikisch et al. } \\
\text { (2008), Peters et al. } \\
\text { (2008) }\end{array}$ \\
\hline & rs1128503 & $\begin{array}{l}\mathrm{A} / \mathrm{C} / \\
\mathrm{G} / \mathrm{T}\end{array}$ & 412 G/? & G (56\%) & $A(44 \%)$ & $\begin{array}{l}\text { Coding } \\
\text { exon }\end{array}$ & & \\
\hline & rs10280101 & $\mathrm{A} / \mathrm{C}$ & None & A (85\%) & C (15\%) & Intron & & \\
\hline & rs7787082 & $A / G$ & None & G (82\%) & $A(18 \%)$ & Intron & & \\
\hline & rs2032583 & $A / G$ & None & A (85\%) & G (15\%) & $\begin{array}{l}\text { Intron } \\
\text { (boundary) }\end{array}$ & & \\
\hline & rs2235040 & $\mathrm{C} / \mathrm{T}$ & None & C (85\%) & $\mathrm{T}(15 \%)$ & $\begin{array}{l}\text { Intron } \\
\text { (boundary) }\end{array}$ & & \\
\hline $\mathrm{TPH} 1$ & rs1800532 & $\mathrm{G} / \mathrm{T}$ & None & G (56\%) & $\mathrm{T}(44 \%)$ & Intron & $\begin{array}{l}\text { Fluvoxamine; } \\
\text { paroxetine; } \\
\text { citalopram; } \\
\text { typical } \\
\text { neuroleptics }\end{array}$ & $\begin{array}{l}\text { Serretti et al. (2001b,c), } \\
\text { Anttila et al. (2007), Ham } \\
\text { et al. (2007), Viikki et al. } \\
\text { (2010) }\end{array}$ \\
\hline \multirow{3}{*}{$\mathrm{TPH} 2$} & rs 10897346 & $\mathrm{C} / \mathrm{T}$ & No data & $\begin{array}{l}\text { No freq. } \\
\text { data }\end{array}$ & $\begin{array}{l}\text { No freq. } \\
\text { data }\end{array}$ & No data & & \\
\hline & rs1487278 & $\mathrm{C} / \mathrm{T}$ & None & $\mathrm{T}(78 \%)$ & C (22\%) & Intron & & \\
\hline & rs2171363 & $A / G$ & None & G (64\%) & A (36\%) & Intron & & \\
\hline COMT & rs4680 & $A / G$ & $\begin{array}{l}158 \\
V / M\end{array}$ & G (51\%) & A (49\%) & $\begin{array}{l}\text { Coding } \\
\text { exon }\end{array}$ & $\begin{array}{l}\text { Fluoxetine; } \\
\text { paroxetine; } \\
\text { citalopram }\end{array}$ & $\begin{array}{l}\text { Benedetti et al. (2009), } \\
\text { Tsai et al. (2009a), } \\
\text { Kocabas et al. (2010) }\end{array}$ \\
\hline \multirow[t]{4}{*}{ MAO-A } & uVNTR & $\begin{array}{l}\text { No } \\
\text { data }\end{array}$ & No data & $\begin{array}{l}\text { No freq. } \\
\text { data }\end{array}$ & $\begin{array}{l}\text { No freq. } \\
\text { data }\end{array}$ & Promoter & $\begin{array}{l}\text { Mirtazapine; } \\
\text { fluoxetine }\end{array}$ & $\begin{array}{l}\text { Peters et al. (2004), Tadic } \\
\text { et al. (2007), Tzeng et al. } \\
\text { (2009) }\end{array}$ \\
\hline & rs6323 & $\mathrm{G} / \mathrm{T}$ & $297 \mathrm{R} / \mathrm{R}$ & T (73\%) & G (27\%) & $\begin{array}{l}\text { Coding } \\
\text { exon }\end{array}$ & & \\
\hline & rs1465108 & $A / G$ & None & G (70\%) & A (30\%) & Intron & & \\
\hline & rs1799835 & $\mathrm{G} / \mathrm{T}$ & $314 \mathrm{FN}$ & & & $\begin{array}{l}\text { Coding } \\
\text { exon }\end{array}$ & & \\
\hline
\end{tabular}

(Continued) 
Table 1 | Continued

\begin{tabular}{|c|c|c|c|c|c|c|c|c|}
\hline 5-HTTLPR & 44 bp Del/Ins & $\begin{array}{l}\text { long/ } \\
\text { short }\end{array}$ & No data & I (51\%) & s (49\%) & Promoter & $\begin{array}{l}\text { Fluvoxamine; } \\
\text { paroxetine; } \\
\text { citalopram; } \\
\text { fluoxetine; } \\
\text { nortriptyline; } \\
\text { mirtazapine; } \\
\text { sertraline }\end{array}$ & $\begin{array}{l}\text { Zanardi et al. (2001), } \\
\text { Rausch et al. (2002), Arias } \\
\text { et al. (2003), Joyce et al. } \\
\text { (2003), Durham et al. } \\
\text { (2004), Murphy Jr. et al. } \\
\text { (2004), Peters et al. } \\
\text { (2004), Serretti et al. } \\
\text { (2004c), Kraft et al. (2005), } \\
\text { Kim et al. (2006), Smeraldi } \\
\text { et al. (2006), Bozina et al. } \\
\text { (2008), Huezo-Diaz et al. } \\
\text { (2009), Mandelli et al. } \\
\text { (2009), Min et al. (2009), } \\
\text { Mrazek et al. (2009), } \\
\text { Wilkie et al. (2009), Illi } \\
\text { et al. (2010) }\end{array}$ \\
\hline & rs25531 & $A / G$ & None & $\begin{array}{l}\text { No freq. } \\
\text { data }\end{array}$ & $\begin{array}{l}\text { No freq. } \\
\text { data }\end{array}$ & Promoter & & \\
\hline \multirow[t]{5}{*}{ NET } & rs5566 & $\mathrm{C} / \mathrm{G}$ & $369 \mathrm{~A} / \mathrm{P}$ & G (100\%) & C (0\%) & $\begin{array}{l}\text { Coding } \\
\text { exon }\end{array}$ & $\begin{array}{l}\text { Desipramine; } \\
\text { paroxetine; } \\
\text { sertraline; } \\
\text { fluvoxamine; } \\
\text { pindolol; } \\
\text { nortriptyline; } \\
\text { milnacipran; } \\
\text { fluoxetine; } \\
\text { venlafaxine }\end{array}$ & $\begin{array}{l}\text { Yoshida et al. (2004), } \\
\text { Hahn et al. (2005), Kim } \\
\text { et al. (2006), Dong et al. } \\
\text { (2009), Min et al. (2009), } \\
\text { Uher et al. (2009) }\end{array}$ \\
\hline & rs2242446 & $\mathrm{C} / \mathrm{T}$ & None & $\mathrm{T}(73 \%)$ & C (27\%) & $5^{\prime}$ UTR & & \\
\hline & rs1532701 & $A / G$ & None & $A(53 \%)$ & G (47\%) & Intron & & \\
\hline & rs5564 & $A / G$ & None & A (95\%) & G (5\%) & $\begin{array}{l}\text { Intron } \\
\text { (boundary) }\end{array}$ & & \\
\hline & rs1362621 & $A / G$ & None & $\mathrm{A}(76 \%)$ & G (24\%) & Promoter & & \\
\hline DAT & $\begin{array}{l}40-b p \text { in exon } \\
15\end{array}$ & VNTR & No data & $\begin{array}{l}\text { No freq. } \\
\text { data }\end{array}$ & $\begin{array}{l}\text { No freq. } \\
\text { data }\end{array}$ & $3^{\prime}$ UTR & $\begin{array}{l}\text { Mirtazapine; } \\
\text { venlafaxine; } \\
\text { citalopram }\end{array}$ & $\begin{array}{l}\text { Kirchheiner et al. (2006), } \\
\text { Lavretsky et al. (2008) }\end{array}$ \\
\hline $\begin{array}{l}\text { 5-HT1A } \\
\text { receptor }\end{array}$ & rs6295 & $\mathrm{C} / \mathrm{G}$ & None & C (56\%) & G (44\%) & Promoter & $\begin{array}{l}\text { Fluoxetine; } \\
\text { nefazodone; } \\
\text { fluvoxamine; } \\
\text { citalopram }\end{array}$ & $\begin{array}{l}\text { Perez et al. (1997), } \\
\text { Lemonde et al. (2004), } \\
\text { Serretti et al. (2004a), } \\
\text { Arias et al. (2005), Hong } \\
\text { et al. (2006), Parsey et al. } \\
\text { (2006), Yu et al. (2006), } \\
\text { Kato et al. (2009), } \\
\text { Villafuerte et al. (2009) }\end{array}$ \\
\hline
\end{tabular}


Table 1 | Continued

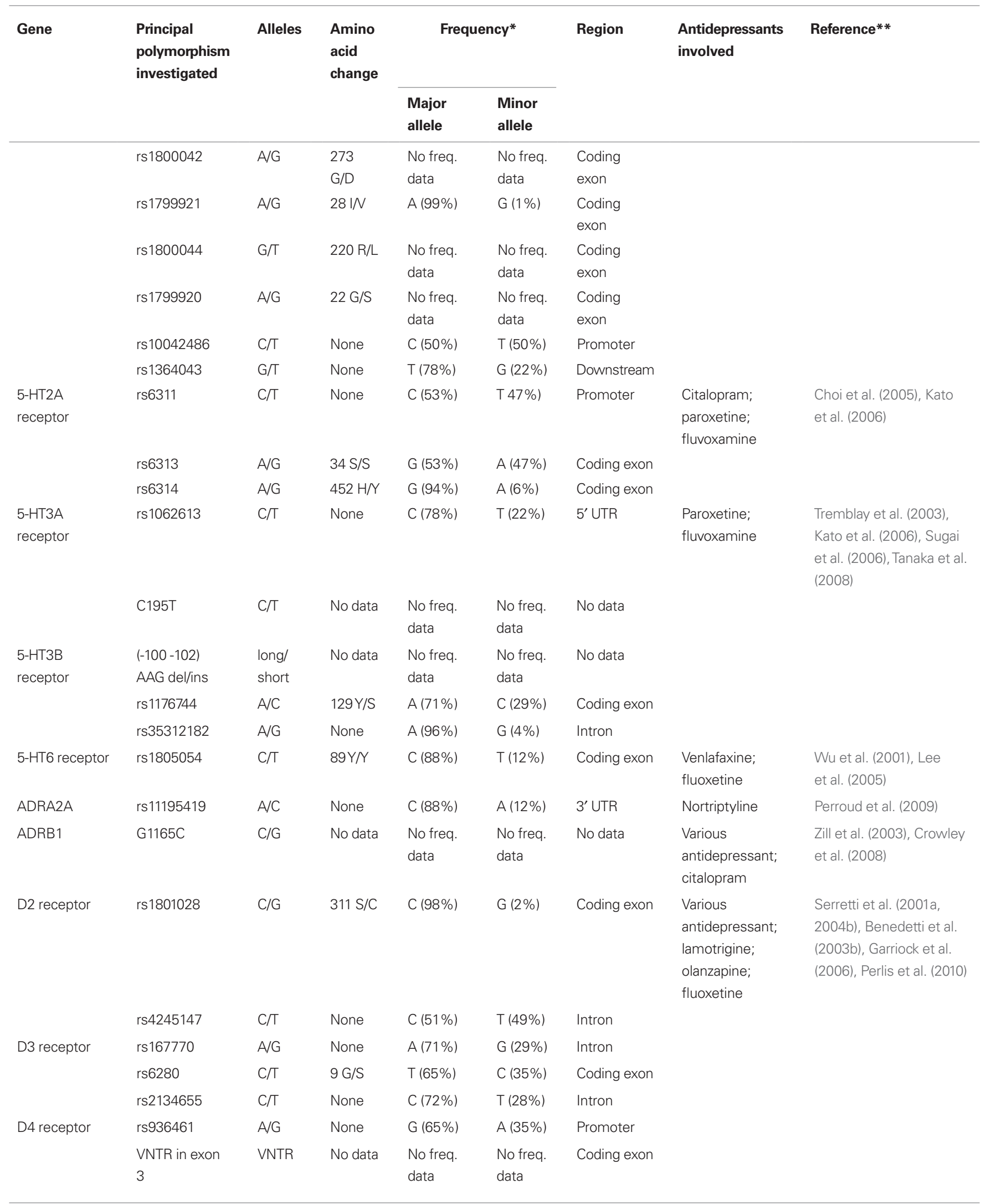




\begin{tabular}{|c|c|c|c|c|c|c|c|c|}
\hline GNB3 & rs5443 & $\mathrm{C} / \mathrm{T}$ & 275 S/S & C (62\%) & T (38\%) & Coding exon & $\begin{array}{l}\text { Fluoxetine; } \\
\text { nortriptyline; } \\
\text { paroxetine; } \\
\text { escitalopram; } \\
\text { mirtazapine }\end{array}$ & $\begin{array}{l}\text { Zill et al. (2000), Joyce } \\
\text { et al. (2003), Serretti et al. } \\
\text { (2003b), Lee et al. (2004), } \\
\text { Hong et al. (2006), Kang } \\
\text { et al. (2007), Wilkie et al. } \\
\text { (2007), Kato et al. } \\
\text { (2008b), Lin et al. (2009), } \\
\text { Keers et al. (2010a) }\end{array}$ \\
\hline \multirow[t]{3}{*}{ CRHR1 } & rs242941 & $\mathrm{G} / \mathrm{T}$ & None & G (69\%) & $\mathrm{T}(31 \%)$ & Intron & Fluoxetine & $\begin{array}{l}\text { Licinio et al. (2004), Liu } \\
\text { et al. (2007) }\end{array}$ \\
\hline & rs1876828 & $A / G$ & None & G (78\%) & A (22\%) & Intron & & \\
\hline & rs242939 & $A / G$ & None & A $(93 \%)$ & G (7\%) & Intron & & \\
\hline \multirow{4}{*}{ GR } & $\mathrm{Bcll}$ & $\begin{array}{l}\text { No } \\
\text { data }\end{array}$ & No data & $\begin{array}{l}\text { No freq. } \\
\text { data }\end{array}$ & $\begin{array}{l}\text { No freq. } \\
\text { data }\end{array}$ & No data & & \\
\hline & rs852977 & $A / G$ & None & A (66\%) & G (34\%) & Intron & & \\
\hline & rs 10482633 & $\mathrm{G} / \mathrm{T}$ & None & T (80\%) & G (20\%) & Intron & & \\
\hline & rs 10052957 & $A / G$ & None & G (65\%) & A (35\%) & Promoter & & \\
\hline BDNF & rs6265 & $\mathrm{C} / \mathrm{T}$ & $66 \mathrm{~V} / \mathrm{M}$ & C (80\%) & $\mathrm{T}(20 \%)$ & Coding exon & $\begin{array}{l}\text { Various } \\
\text { antidepressant; } \\
\text { citalopram; } \\
\text { fluoxetine }\end{array}$ & $\begin{array}{l}\text { Choi et al. (2006), } \\
\text { Gratacos et al. (2008), } \\
\text { Licinio et al. (2009), } \\
\text { Domschke et al. (2010), } \\
\text { Zou et al. (2010a) }\end{array}$ \\
\hline \multirow{4}{*}{ NTRK2 } & rs56142442 & $\mathrm{C} / \mathrm{T}$ & 794 P/P & $\begin{array}{l}\text { No freq. } \\
\text { data }\end{array}$ & $\begin{array}{l}\text { No freq. } \\
\text { data }\end{array}$ & Coding exon & & \\
\hline & rs2289658 & $\mathrm{C} / \mathrm{T}$ & None & Т (96\%) & C (4\%) & $\begin{array}{l}\text { Intron } \\
\text { (boundary) }\end{array}$ & & \\
\hline & rs2289657 & $\mathrm{A} / \mathrm{C}$ & $600 \mathrm{l} / \mathrm{I}$ & C (95\%) & $A(5 \%)$ & Coding exon & & \\
\hline & rs2289656 & $A / G$ & None & G (82\%) & A (18\%) & $\begin{array}{l}\text { Intron } \\
\text { (boundary) }\end{array}$ & & \\
\hline
\end{tabular}

**The table indicates the main references.

*The allele frequencies are referred to Caucasians.

of the gene allowed a classification in phenotypes, with a group of subjects labeled as EM, another one with impaired catalytic capacity, called PM (Smith et al., 1998a,b); and an UM group (Rudberg et al., 2008). In conclusion, the pharmacokinetics of ADs is significantly altered, in particular by CYP2D6 and more marginally by CYP2C19 polymorphisms. However, it is still controversial whether therapeutic efficacy may be improved and/or adverse effects could be prevented by the use of genotyping procedures, particular considering that genotype often do not correspond to a well-defined phenotype as state above. With regard to this, the recent approval by the FDA of the pharmacogenetic test, the AmpliCyp CYP450 Test (Roche Molecular System Inc.), assessing both polymorphic genes CYP2D6 and CYP2C19, may be of help to validate studies on personalized therapy of depression. 
Table 2 | Cytochrome P450 isoforms responsible for the biotransformation of antidepressants. Based on Spina et al. (2008).

\begin{tabular}{ll}
\hline Antidepressant & $\begin{array}{l}\text { Enzymes responsible for } \\
\text { biotransformation }\end{array}$ \\
\hline $\begin{array}{l}\text { Tricyclic antidepressants } \\
\text { (demethylation) } \\
\text { Tricyclic antidepressants } \\
\text { (hydroxylation) }\end{array}$ & CYP2C19, CYP1A2, CYP3A4 \\
Fluoxetine & CYP2D6 \\
Paroxetine & CYP2D6, CYP2C9, CYP2C19, \\
Fluvoxamine & CYP3A4 \\
Sertraline & CYP2D6, CYP3A4 \\
Citalopram & CYP1A2, CYP2D6 \\
Escitalopram & CYP2C9, CYP2C19, CYP2D6, \\
Venlafaxine & CYP3A4 \\
Duloxetine & CYP2C19, CYP2D6, CYP3A4 \\
Mirtazapine & CYP2C19, CYP2D6, CYP3A4 \\
Reboxetine & CYP2D6, CYP3A4 \\
Trazodone & CYP2D6, CYP1A2 \\
Nefazodone & CYP2D6, CYP1A2, CYP3A4 \\
Bupropion & CYP3A4 \\
Agomelatine & CYP3A4 \\
\hline & CYP3A4 \\
CYP2B6 \\
CYP1A2
\end{tabular}

\section{P-GLYCOPROTEIN}

P-glycoprotein is a member of the ATP-binding cassette superfamily of membrane transport proteins encoded by the ATP-binding cassette, subfamily B, member 1 (ABCB1) gene [alternate name multidrug resistance protein 1 (MDR1)], it is responsible for the efflux of many drugs. It represents a major component of the blood-brain barrier (Schinkel et al., 1994) and the intestinal barrier (Van Asperen et al., 1998), and it contributes to renal and biliary elimination of drugs (Kusuhara et al., 1998; Chiou et al., 2000). Because of its location at the blood-brain barrier, Pgp may regulate the concentration of $\mathrm{ADs}$ in the brain. For paroxetine, venlafaxine, and fluoxetine the data indicate that they might be Pgp substrates; for citalopram the data are conflicting (Rochat et al., 1999; Uhr et al., 2000). Several variants of $A B C B 1$ are known (Kioka et al., 1989; Mickley et al., 1998; Hoffmeyer et al., 2000; Ito et al., 2001), among these three-C3435T (rs1045642), C1236 (rs1128503), and G2677T (rs2032582) - have been associated with altered Pgp activity. Studies investigating the influence of these functional polymorphisms on ADs response have given contradictory results (Roberts et al., 2002; Laika et al., 2006; Fukui et al., 2007). Indeed, while some authors found positive associations between rs2032582 (Kato et al., 2008a; Nikisch et al., 2008) or rs1045642 (as well as haplotype with rs2032582 and rs1128503; (Kato et al., 2008a) and AD response or side effects (nortriptylineinducted postural hypotension; (Roberts et al., 2002), other authors failed to find positive association for rs2032582 and rs1045642 (GexFabry et al., 2008; Mihaljevic Peles et al., 2008), also considering together with rs1128503 (Peters et al., 2008). Finally negative findings have been reported also for rs10280101, rs7787082, rs2032583, rs2235040 (Perlis et al., 2010), and rs2032582 (Laika et al., 2006).

\section{PHARMACODYNAMICS MONOAMINE METABOLIC ENZYMES Tryptophan hydroxylase}

Tryptophan hydroxylase is an enzyme involved in the synthesis of serotonin. There are two distinct TPH genes that encode two different homologous enzymes TPH1 and TPH2. TPH1 is mostly expressed in tissues that express serotonin in the skin, gut, and pineal gland but it is also expressed in the central nervous system (CNS). TPH2 is exclusively expressed in neuronal cell types and is the predominant isoform in the CNS. TPH gene has been considered one of the most promising genes concerning the genetic modulation of $\mathrm{AD}$ response. Several studies found an association between TPH1 polymorphisms and suicidal behavior and worse response to SSRIs (Serretti et al., 2001b,c; Ham et al., 2007). Unfortunately following studies found controversial results (Yoshida et al., 2002; Rujescu et al., 2003; Bellivier et al., 2004; Peters et al., 2004; Serretti et al., 2004c; Ham et al., 2005; Hong et al., 2006; Kato et al., 2007; Illi et al., 2009). Nevertheless recently studies have shown an association between rs1800532 and $\mathrm{AD}$ response, concerning both clinical response (Anttila et al., 2007; Viikki et al., 2010) and side effect profile (Secher et al., 2009), suggesting that the role of this polymorphisms is not yet deeply understood and needs further investigation, particularly considering also other polymorphisms in the same gene and/or in other correlated genes [like 5-HT2A, G protein beta 3 subunit (GNB3), and COMT; (Anttila et al., 2007; Secher et al., 2009]. Also TPH2 polymorphisms have been associated with $\mathrm{AD}$ response: rs1843809, rs1386494, and rs1487276 (Peters et al., 2004), rs10897346 and rs1487278 (Tzvetkov et al., 2008), rs2171363 (Tsai et al., 2009b). Although these results need to be clearly replicated, overall these data suggested a role for TPH2 gene in $\mathrm{AD}$ pharmacogenetics.

\section{Catechol-0-methyltransferase}

Catechol-O-methyltransferase is one of several enzymes that degrade catecholamines such as dopamine, epinephrine, and norepinephrine (NE). COMT is an intracellular enzyme located in the postsynaptic neuron. The COMT gene have several allelic variants, among these the most well-studied is rs4680, results in a change in the enzyme structure [Val(108/158)Met], which influences activity (high activity in $\mathrm{Val} / \mathrm{Val}$, intermediate activity in $\mathrm{Val} / \mathrm{Met}$, and low activity in Met/Met genotype; (Lachman et al., 1996). This polymorphism was associated with $\mathrm{AD}$ treatment, in particular rs4680 seems to influence fluoxetine and paroxetine response (Benedetti et al., 2009; Tsai et al., 2009a). However, other studies showed contrasting results with other drugs (Szegedi et al., 2005; Arias et al., 2006; Baune et al., 2008a; Yoshida et al., 2008; Benedetti et al., 2009). Particularly Met/ Met genotype has been associated both with better (Baune et al., 2008a; Yoshida et al., 2008; Benedetti et al., 2009; Tsai et al., 2009a) and worse response (Szegedi et al., 2005; Arias et al., 2006). On the other hand, Hilli et al. (2009) did not find any association between this variant and $\mathrm{AD}$ response. Moreover stressful life events do not seem to interact with rs4680 to predict treatment outcome (Bukh et al., 2010). Recently Perlis et al. (2009a) and Kocabas et al. (2010) investigated other SNPs within the COMT founding more or less association with citalopram or other $\mathrm{AD}$ response. Although so far no replication studies have been performed, this result supports the role of COMT gene variants on the $\mathrm{AD}$ response. 


\section{Monoamine oxidase A}

Monoamine oxidases are a family of enzymes that catalyze the oxidation of monoamines. In humans there are two types of $\mathrm{MAO}$ : $\mathrm{MAO}-\mathrm{A}$ and $\mathrm{MAO}-\mathrm{B}$, and both are found in CNS, in particular in neurons and astroglia. The MAO-A, coded by the MAO-A gene, metabolizes several important amines and catecholamines including dopamine, serotonin, and NE. Polymorphism in the gene's promoter region is due to a repetitive sequence [variable number tandem repeat (VNTR)] located $1.2 \mathrm{~kb}$ upstream of the MAO-A gene, regulates the activity of the MAO-A gene and have been linked to variations in the biological activity and also influences the concentration of serotonin (Sabol et al., 1998). Because the activity of MAO-A influences neurotransmitter concentrations, polymorphisms in these genes may affect $\mathrm{AD}$ response. Researchers like Tadic et al. (2007) and more recently Tzeng et al. (2009) reported that the VNTR polymorphism in the MAO-A gene promoter region was associated with mirtazapine response. Nevertheless, as a matter of fact, several reports did not found any correlation between this polymorphism and the AD response (Cusin et al., 2002; Muller et al., 2002; Yoshida et al., 2002; Peters et al., 2004). Other polymorphisms within this gene were more marginally studied, with some positive but not replicated results. Particularly Peters et al. (2004) reported an association between rs 1465108 and rs6323 and fluoxetine response whilst Tadic et al. (2007) found an association between rs1799835 and mirtazapine response only in the female sample). Finally an effect of the rs6323 genotype on the placebo response has been reported (Leuchter et al., 2009).

\section{MONOAMINE TRANSPORTERS \\ Serotonin transporter (SLC6A4)}

The serotonin transporter (SERT or SLC6A4) regulates brain serotonin neurotransmission by transporting the neurotransmitter serotonin from synaptic space to presynaptic neurons. It is the principal site of action of many ADs (mainly SSRI, SNRI, TCA) and it represents a target of primary interest in the AD pharmacogenetics. The most investigated variant of this gene is located in the promoter region (5-HTTLPR) and it is able to impact the expression of the SERT. This polymorphism was firstly described in 1996 by Heils et al. (1996) as an insertion/deletion of 44 bp involving $2 \mathrm{U}$ in a sequence of 16 repeated elements: the long (1) allele has twice the expression in the basal state than the short (s) form. 5-HTTLPR polymorphism has been studied in association with affective symptomatology (anxiety disorders, substance abuse, bipolar disorder, eating disorders, and depression) and with pathological behaviors and personality traits related to anxiety, impulsivity, and stress (Serretti et al., 2006). Moreover, several reports found an association with AD response, in particular, studies in Caucasians showed a positive association between $\mathrm{L}$ allele and better response (Smeraldi et al., 1998; Pollock et al., 2000; Zanardi et al., 2000, 2001; Rausch et al., 2002; Arias et al., 2003; Joyce et al., 2003; Durham et al., 2004; Murphy Jr. et al., 2004; Serretti et al., 2004c; Bozina et al., 2008; Huezo-Diaz et al., 2009; Mandelli et al., 2009; Mrazek et al., 2009; Illi et al., 2010) although negative findings have been reported as well (Hu et al., 2007; Kraft et al., 2007; Dogan et al., 2008; Maron et al., 2009; Wilkie et al., 2009; Baffa et al., 2010; Reimherr et al., 2010). A meta-analysis performed by
Serretti et al. (2007b) showed a significant association between the s/s variant of 5-HTTLPR and remission rate and between both $\mathrm{s} / \mathrm{s}$ and $\mathrm{s} / \mathrm{l}$ variants and response rate. Nonetheless, a more recent meta-analysis performed by Taylor et al. (2010) failed to replicate this result, probably because they did not consider separately Caucasian and Asian samples. Other studies focused on the possible interaction between genetic and environment finding that stressful life events could interact with 5-HTTLPR genotype to determinate AD response (Bukh et al., 2009; Mandelli et al., 2009; Keers et al., 2010b), although this topic is still controversial (Coventry et al., 2010). These findings were found to be more consistent in Caucasian than in Asian samples, probably for a different prevalence of this mutation in diverse ethnicities. Interestingly Murphy Jr. et al. (2004) showed an interaction between the HTTLPR genotype and the $\mathrm{AD}$ used on the side effect profile suggesting that the effect of this polymorphism on outcome may depend on the mechanism of $\mathrm{AD}$ action as well. Another polymorphism influencing SERT expression, described as a 17-bp VNTR polymorphism, was identified by Ogilvie et al. (1996) within intron 2 (STin2). Some evidences suggested this polymorphism as a risk factor for depressive disorder (Ogilvie et al., 1996; Gutierrez et al., 1998; MacKenzie and Quinn, 1999) and suicide behavior (Gaysina et al., 2006; Lopez de Lara et al., 2006), creating a synergistic effect with 5-HTTLPR (Hranilovic et al., 2004). Moreover, different authors reported an effect of STin2 on AD response (Kim et al., 2000, 2006; Peters et al., 2004; Bozina et al., 2008; Min et al., 2009; Mrazek et al., 2009; Wilkie et al., 2009), even though not consistently (Ito et al., 2002; Dogan et al., 2008; Huezo-Diaz et al., 2009). More recently rs25531, a SNP located just upstream of the 5-HTTLPR, was found to impact the response to $\mathrm{AD}$ pharmacotreatment and, consistently, it was shown to modulate the effect of the other 5-HTTLPR alleles (Kraft et al., 2005; Smeraldi et al., 2006). Nevertheless the results are still controversial with both negative (Kraft et al., 2007; Maron et al., 2009; Baffa et al., 2010) and positive findings (Kraft et al., 2005; Mrazek et al., 2009; Bonvicini et al., 2010).

\section{Norepinephrine transporter (SLC6A2)}

The norepinephrine transporter or NET [or noradrenaline transporter (NAT) ] is encoded by the SLC6A2 gene. It is a monoamine transporter that transports the neurotransmitters NE (noradrenaline) from the synapse back to cytosol, hence other transporters vesicular monoamine transporter (VMAT) sequester NE into vesicles for later storage and release. Several investigators have studied the relationship between NET genetic polymorphisms and susceptibility to psychiatric disorders, including MD, bipolar disorder, schizophrenia, and alcohol dependence (Owen et al., 1999; Leszczynska-Rodziewicz et al., 2002; Samochowiec et al., 2002; Zill et al., 2002), without observing major findings. Several genetic variants are known in the human NET gene: rs5566 (A369P), rs5563 (N292T), rs5558 (F528C), rs5569 (G1287A), and rs2242446 (T-182C) variants were proved to be functional and impact the AD effect (Yoshida et al., 2004; Hahn et al., 2005; Kim et al., 2006). With particular regard to AD response, rs5569, a silent mutation is associated with the cerebrospinal fluid concentration of 3-methoxy-4-hydroxyphenylglycol, a major NE metabolite (Jonsson et al., 1998), and with the response to methylphenidate, 
a drug with noradrenergic action, in attention deficit hyperactivity disorder (ADHD; (Yang et al., 2004). The association between this polymorphism and the $\mathrm{AD}$ response was previously examined in Japanese patients by Yoshida et al. (2004): they reported that the NET G1287A polymorphism (A/A genotype) was associated with the onset of response but not the final clinical improvement. Moreover, Kim et al. (2006) showed a positive association between G/G rs5569 genotype and better response to nortriptyline, although no effect on SSRIs response has been detected. The NET T-182C polymorphism was first reported by Zill et al. (2002) and the presence of the $\mathrm{T}$ allele was associated with a superior response to milnacipran (Yoshida et al., 2004; for a review see Higuchi, 2010). Consistently one other study did not find any association between these polymorphisms and SSRIs (fluoxetine, paroxetine, or citalopram) or venlafaxine response in an Asiatic sample of depressed patients (Min et al., 2009). Recently other NET polymorphisms have been investigated: Uher et al. (2009) showed an association between rs60329 and rs1532701 polymorphism and favorable response to treatment with nortriptyline, and Dong et al. (2009) found that the rs5564 and rs1362621 were associated with remission with desipramine and fluoxetine treatment. Nevertheless, Baffa et al., 2010) did not found any association with seven polymorphisms in the promoter, intronic and exonic region of NET (rs35915, rs28386840, rs168924, rs2242446, rs36017, rs47958, rs171798). However, results are not unequivocal, and replication studies are warranted.

\section{Dopamine transporter}

The DAT (SLC6A3) acts to terminate dopaminergic neurotransmission through reuptake of dopamine from the synaptic cleft into presynaptic neurons. DAT is thought to be implicated in several dopamine-related disorders, including ADHD (Barr et al., 2000), schizophrenia (Prata et al., 2009), and alcoholism (Heinz et al., 2004). SLC6A3 gene has a VNTR at the $3^{\prime}$ end (rs28363170; Sano et al., 1993). This polymorphism has been studied in association with several diseases, including bipolar affective disorders (Waldman et al., 1997; Greenwood et al., 2001). AD drugs, in particular SSRIs, modulate availability of DAT, and dopaminergic mechanisms may play an important role in AD drug action (Ichikawa and Meltzer, 1995; Smith et al., 2000; Kugaya et al., 2003; Willner et al., 2005; Zhou et al., 2005). However, according to our best knowledge, the relationship between the DAT polymorphism and AD response has been weakly studied. Kirchheiner et al. (2006) showed an association between the $9 / 10$ and 9/9 genotypes and a higher risk of poorer and slower response to various $\mathrm{AD}$ drugs than the 10/10 genotype. Moreover, the 10/10 genotype seems to be associated with an endophenotype (Gottesman and Gould, 2003) of late-life depression that responds preferentially to methylphenidate added to a SSRI (Lavretsky et al., 2008).

\section{MONOAMINE RECEPTORS}

\section{5-Hydroxytryptamine 1 A or serotonin-1A receptors}

Serotonin-1A receptors is a Gprotein-coupled receptor located both pre- and post-synaptically and widely distributed in regions that receive serotonergic input from the raphe nuclei: the frontal cortex, septum, amygdala, hippocampus, and hypothalamus
(Lesch and Gutknecht, 2004; Sharp et al., 2007). The 5-HT1A receptor also serves as the predominant (somatodendritic) autoreceptor of the raphe nuclei, reducing the firing rate of these neurons, the amount of serotonin released per action potential, and the synthesis of the neurotransmitter; and thus by implication, the serotonergic activity of its projection areas (Wang and Aghajanian, 1977; Verge et al., 1985; Sprouse and Aghajanian, 1986; Blier and de Montigny, 1987; Hutson et al., 1989; Meller et al., 1990; Hjorth and Sharp, 1991; Kreiss and Lucki, 1994). The 5-HT1A receptor is coded by the 5-hydroxytryptamine receptor 1A (HTR1A) gene. A role for this gene in the $\mathrm{AD}$ response has been postulated because several AD desensitize raphe 5-HT1A autoreceptors, leading to an enhancement of the serotonergic neurotransmission that could be associated with the AD effect of these drugs. Moreover there are some evidences that the block of the 5-HT1A autoreceptors may accelerate the AD action (Perez et al., 1997). The most investigated HTR1A variants are: C(-1019)G (rs6295); Gly272Asp (rs1800042); Ile28Val (rs1799921); Arg219Leu (rs1800044); and Gly22Ser (rs1799920). Among these, the most investigated one concerning AD response is rs6295, which is located in the promoter region of the gene. The rs6295 $\mathrm{G}$ allele has been associated with an up regulation of the expression of the receptor (Lemonde et al., 2003; Albert and Lemonde, 2004), moreover there are some evidences suggesting that $G$ allele carriers have higher risks for depression and suicidal behavior and of being more resistant to AD treatment (Lemonde et al., 2003, 2004; Serretti et al., 2004a; Arias et al., 2005; Hong et al., 2006; Parsey et al., 2006; Yu et al., 2006; Kato et al., 2009; Villafuerte et al., 2009). In particular, Lemonde et al. (2004) reported that AD response to the SSRI fluoxetine, NARI nefazodone, and 5-HT1A agonist flibanserin, was associated with this polymorphism. Nonetheless other authors reported conflicting results (Peters et al., 2004; Serretti et al., 2004a; Mandelli et al., 2007; Noro et al., 2010). Noteworthy, Yu et al. (2006) found an association between rs6295 and AD response only in females, showing an interaction with gender, and Baune et al. (2008b) showed an association only in patients with melancholic depression. No interaction has been found between rs6295 and stressful life events with the AD response (Bukh et al., 2010). Another SNP associated with better AD response was rs1800042, although negative results are reported as well (Suzuki et al., 2004; Yu et al., 2006; Levin et al., 2007). With regard to drug related adverse events, neither rs1800042 nor rs6295 seem to be significantly associated to paroxetine discontinuation syndrome (Murata et al., 2010). Also other 5-HT1A polymorphisms were studied in association with $\mathrm{AD}$ response. A recent paper reported that $\mathrm{rs} 10042486 \mathrm{C} / \mathrm{C}$ and rs $1364043 \mathrm{~T} / \mathrm{T}$ genotypes were strongly associated with a better response to AD drugs (Kato et al., 2009). All these data suggested that other 5-HT1A gene variants need to be considered in order to better elucidate the role of this gene on $\mathrm{AD}$ response (Drago et al., 2008).

\section{5-HT2A receptor}

5-Hydroxytryptamine $1 \mathrm{~A}$ receptor is a $\mathrm{G}$ protein-coupled receptor coded by the HTR2A gene; it is expressed widely throughout the CNS, near most of the serotonergic terminal rich areas, including neocortex (mainly prefrontal, parietal, and somatosensory 
cortex) and the olfactory tubercle. An increasing number of studies suggested that HTR2A levels and activity are altered in psychiatric disorders like MDD (Yatham et al., 1999; Meyer et al., 2001; Yamauchi et al., 2005; Bhagwagar et al., 2006), evidence supported also by animal studies (Skrebuhhova et al., 1999). The most widely investigated polymorphisms of HTR2A gene are: A-1438G (rs6311), C102T (rs6313), and His452Tyr (rs6314). HTR2A variations have been investigated as functional candidates in several psychiatric disorders such as schizophrenia, ADHD, affective disorders, eating disorders, anxiety disorders, obsessive compulsive disorders, suicide, Alzheimer's disease. In particular, several studies have been shown an association between rs6311 polymorphism and mood disorders, bipolar disorder, and MDD (Chee et al., 2001; Choi et al., 2004), such as with AD response (Choi et al., 2005; Kato et al., 2006). A weak link has been found between the rs6313 SNP and schizophrenia, moreover, this polymorphism has been studied in relation to suicide attempts (Williams et al., 1996; Vaquero-Lorenzo et al., 2008). Consistently, Minov et al. (2001) showed an association between the 5-HT2A rs6313 SNP (102T/C) and $\mathrm{AD}$ response. These two variants (rs6311 and rs6313) are in linkage disequilibrium (LD) and they can be considered together (Spurlock et al., 1998), therefore studies by Choi et al. (2005) and Kato et al. (2006) may be considered replications of results from Minov et al. (2001). On the other side there are studies that failed to replicate positive results (Cusin et al., 2002; Sato et al., 2002; Peters et al., 2004; Yoshida et al., 2004; Hong et al., 2006; Suzuki et al., 2006; Illi et al., 2009). Several other variants have been reported to influence AD response (Cusin et al., 2002; Peters et al., 2004, 2009; McMahon et al., 2006; Perlis et al., 2009b; Uher et al., 2009; Wilkie et al., 2009; Horstmann et al., 2010; Kishi et al., 2010; Lucae et al., 2010). Overall data suggested a role for the 5-HT2A gene in the AD response, although a wider knowledge of this gene is needed in order to better disentangle this issue (Serretti et al., 2007a).

\section{5-HT3A, $3 B$ receptors}

The 5-HT3 receptor is expressed throughout the central and peripheral nervous systems and mediates a variety of physiological functions; it is the only ion channel subtype in the serotonin family. Five different subunits, A-E, of the 5-HT3 receptor have been identified. Association studies have been carried out to establish causal relationships between genetic variants within genes encoding 5-HT3A and 5-HT3B and side effects profile rather than clinical response. Yamada et al. (2006) showed an association between haplotype block in the 5-HT3B gene [that includes Y129S (rs1176744) polymorphism] and MD in women and in patients with bipolar affective disorder (Frank et al., 2004). Likewise, a common variation in the regulatory region of the 5-HT3A gene C178T has been associated with bipolar affective disorder in Caucasians (Niesler et al., 2001), although a recent study on Japanese patients did not confirm this result (Yamada et al., 2006). Consistently HTR3A rs1062613 (C178T) and two polymorphisms in HTR3B (-100-102 AAG deletion variant and rs1176744) have been found to be associated with chemotherapy and paroxetine treatment induced vomiting and nausea (Tremblay et al., 2003; Kato et al., 2006; Sugai et al., 2006; Tanaka et al., 2008). Nevertheless, studies on gastrointestinal side effects during
SSRIs treatment showed no association with HTR3B rs1176744 (Suzuki et al., 2006; Tanaka et al., 2008), HTR3A rs1062613 and C195T (Sugai et al., 2006), as well as no association has been found between HTR3A (rs1062613) and HTR3B (rs35312182 and rs1176744) polymorphisms and paroxetine discontinuation syndrome (Murata et al., 2010).

\section{5-HT6 receptor}

The 5-HT6 receptor is a G protein-coupled receptor which is expressed almost exclusively in the brain. Genetic variants within this gene likely have an effect on brain and several studies have investigated whether 5-HT6 polymorphisms are associated with brain-related variables, such as neuropsychiatric disorders. In this regard, several studies showed an implication of this gene in some behavior trait (Ballaz et al., 2007; Mitchell et al., 2007). Moreover, it seems to be involved in AD mechanism (Svenningsson et al., 2007; Wesolowska and Nikiforuk, 2007). The C267T variant (rs1805054), in the first exon, may has a role in the modulation of $\mathrm{AD}$ response as well (Kohen et al., 1996; Lee et al., 2005). Indeed, this polymorphism (rs1805054) has been investigated for association with AD response in several studies. Despite preliminary negative results (Wu et al., 2001), a subsequent study reported that C/T carriers showed better AD response (Lee et al., 2005). Nevertheless, this finding has not been replicated by further studies (Illi et al., 2009; Wilkie et al., 2009).

\section{Adrenoreceptor beta-1 and adrenoreceptor alpha-2}

The ADRB1 and ADRA2A are G protein associated receptor: ADRB1 stimulates adenylate cyclase while alpha 2 adrenoreceptor inactivates adenylate cyclase. A recently identified functional polymorphism in the ADRB1 G(1165)C leading to the amino acid variation Gly389Arg may play a functional role, and it was associated with an enhanced coupling to the stimulatory Gs protein and increased adenylate cyclase activation, resulting in a better and faster response to AD treatment (Zill et al., 2003). Nevertheless, Crowley et al. (2008) failed to confirm the relevance of this gene in modulating the response to citalopram treatment. ADRA2A gene, it seems to be relate to the pretreatment hypothalamicpituitary-adrenal (HPA) axis hyperactivity and increased adrenocorticotropin in male depressed patients (Haefner et al., 2008). Recently, Perroud et al. (2009) showed an association between rs11195419 ADRA2A polymorphism and suicidality ideation among nortriptyline treated patients.

\section{Dopamine receptors}

Dopamine receptors are divided into D1-like family (D1 and D5, which are coupled to a Gs protein and activate adenylate cyclase), and D2-like family (D2, D3, and D4, which are coupled to a Gi protein and inhibit adenylate cyclase). Only the D2-like family was associated to depressive disorder. Focusing on AD response, we have some line of evidence suggesting a role for D2 receptor as well (Maj et al., 1989; Dziedzicka-Wasylewska and Solich, 2004; Willner et al., 2005). A functional polymorphism (S311C, rs1801028) within D2 receptor gene has been repeatedly investigated without finding any influence on $\mathrm{AD}$ response (Serretti et al., 2001a, 2004b; Benedetti et al., 2003b). However, a recent study showed an association between D2 rs4245147 SNP and 
lamotrigine response in a sample of bipolar depressed patients (Perlis et al., 2010), suggesting a role of this gene in $\mathrm{AD}$ response as well. In the same study (Perlis et al., 2010) founded an association between three D3 receptor SNPs (rs167770, rs6280, and rs2134655) and olanzapine/fluoxetine combination response in a sample of bipolar I depressed patients. Moreover, they reported a marginal association between D4 receptor SNP rs936461 and lamotrigine response (Perlis et al., 2010). Several studies investigated VNTR polymorphism in exon 3 of D4 receptor gene, in relationship with $\mathrm{AD}$ response, unfortunately with negative results (Serretti et al., 1999, 2001a), except for Garriock et al. (2006) who found a significant modulation effect on various AD medications.

\section{INTRACELLULAR SIGNAL TRANSDUCTION PATHWAYS $G$ protein beta 3 subunit}

The $\beta 3$ subunit of the $G$ protein complex, encoded by GNB3 gene, is present in all cells of the body and it has a key role in the downstream signaling cascade following monoamine receptors activation (Hamm, 1998). For this reason a possible involvement in the pharmacogenetic of $\mathrm{AD}$ response has been suggested as well. The C825T (rs5443) polymorphism is the most investigated variant within the GNB3 gene in this field. It was associated with AD treatment response; particularly the $\mathrm{T}$ variant seems to predict better AD response. Nonetheless also in this case both opposite and negative results have been reported as well (Zill et al., 2000; Joyce et al., 2003; Serretti et al., 2003b; Lee et al., 2004; Hong et al., 2006; Kang et al., 2007; Wilkie et al., 2007; Kato et al., 2008b; Lin et al., 2009; Keers et al., 2010a). Finally, Anttila et al., 2007) failed to find any association between this polymorphism and ECT response in depressed patients.

\section{HYPOTHALAMIC-PITUITARY-ADRENAL AXIS AND STRESS HORMONE SYSTEM \\ CRH receptors (CRHR1 and CRHR2)}

The principal neuro-endocrine regulator of the HPA axis is the $\mathrm{CRH}$, which plays an important role in coordinating the endocrine, autonomic, immune and behavioral responses to stress. Several studies showed a key role of CHR in depression (Nemeroff et al., 1984, 1988; Brady et al., 1992; Raadsheer et al., 1994; Michelson et al., 1997; Gold and Chrousos, 2002; Liu et al., 2002a). Consistently most AD treatment seems to attenuate or normalize HPA axis activity (De Bellis et al., 1993; Ising et al., 2005; Ising and Holsboer, 2007; Schule et al., 2009). In the CNS there are two fundamental subtypes of CRH receptors: CRHR1 and CRHR2. CRHR1 gene is considered to play a key role in mediating the CRH elicited effects in depression and anxiety (Van Pett et al., 2000). Moreover, CRHR1 antagonists have consistently demonstrated $\mathrm{AD}$ properties in experimental animals and humans (Seymour et al., 2003; Overstreet and Griebel, 2004; Kehne, 2007) even if this finding was not constantly replicated (Binneman et al., 2008). Several polymorphisms, in particular the rs242941 G/G genotype and one haplotype including two other SNPs beyond rs242941 (rs1876828 and rs242939), were found to be related to fluoxetine response (Licinio et al., 2004; Liu et al., 2007).

Moreover, Papiol et al., 2007 found an association between CRHR2 gene rs2270007 and citalopram response.

\section{Glucocorticoid receptor}

Hyperactivity of HPA axis might be caused by impaired glucocorticoid signaling. Glucocorticoids act through the GR (or NR3C1). Within this gene several polymorphisms have been associated with MDD and AD response. In particular, the BclI and ER22/23EK polymorphisms were associated with susceptibility to develop MD (van Rossum et al., 2006). In addition, the ER22/23EK polymorphism was associated with a faster clinical response to $\mathrm{AD}$ treatment (van Rossum et al., 2006). Recently, these results were not repeated in Korean depressive patients (Lee et al., 2009). Brouwer et al. (2006) found that carriers of the BcII polymorphism have higher baseline ATCH values and they showed a trend toward lower decrease of Hamilton Rating Scale for Depression rates than non-carriers. Finally, the rs852977, rs10482633, rs10052957 polymorphisms were associated with $\mathrm{AD}$ response in the STAR $* \mathrm{D}$ sample, although none of them survived after correction for hypothesis-wide effective number of comparisons (Uher et al., 2009).

\section{C-AMP RESPONSE-ELEMENT BINDING}

An increasing number of studies recently focused on the role of the c-AMP response-element binding (CREB) protein in MDD. As a matter of fact, several studies found a role of CREB both in the etiology and pharmacotherapy of MDD (Sulser, 2002; Blendy, 2006). CREB1 has also been found to be associated with AD response in depressed patients (Wilkie et al., 2007) and with lithium response in patients with bipolar disorder (CREB1-1H and CREB1-7H SNPs; Mamdani et al., 2008). Further, rs4675690, a SNP located at the $5^{\prime}$ of CREB1, was found to have a role in suicidal behaviors in patients with MD (Perlis et al., 2007b) and, along with rs7569963, to be associated with anger expression in men suffering from MD (Perlis et al., 2007a). Despite some negative results (Burcescu et al., 2005; Hettema et al., 2009), current evidence suggests that CREB1 could play an important role both in the development of MDD and related features as well as in the ADs response like showed in several studies on animal models (Thome et al., 2000; Kuipers et al., 2006; Tardito et al., 2006; Boer et al., 2010). The CREB1 polymorphisms are still poorly investigated in the field of pharmacogenetic of AD response, resistance and remission. Dong et al. (2009), like Wilkie et al. (2007), failed to find any association between several CREB polymorphisms and AD response, although they showed a significant association between one SNP (rs3730276) and MDD. Recently, Serretti et al. (2011) suggested that some alleles or haplotypes within CREB1 could be related to treatment resistance but not to response and remission to current $\mathrm{AD}$ treatment as well as to a diagnosis of MD. Finally, Perlis et al. (2007a) suggested a role of genetic variants within CREB gene on treatment-emergent suicidal ideation during citalopram treatment. Interestingly they found significant associations only in men, suggesting a significant gene $\times$ sex interaction.

\section{BRAIN-DERIVED NEUROTROPHIC FACTOR}

Brain-derived neurotrophic factor, a member of the neurotrophin family of survival-promoting molecules, plays an important role in the growth, development, maintenance, and function of several neuronal systems (Acheson et al., 1995). There is growing evidence that BDNF can be relevant in mood disorders and that modulation of its biosynthesis following prolonged $\mathrm{AD}$ treatment may 
contribute to neuroplastic changes required for clinical response (Calabrese et al., 2007; Reagan et al., 2007). There are several studies that suggested a role of the BDNF in the mechanism of action of AD drugs (Conti et al., 2007; Rogoz et al., 2007). The reported increase in BDNF mRNA expression after AD treatment is a cornerstone of the BDNF hypothesis of AD action (Jacobsen and Mork, 2004). Several evidences support an influence of BDNF polymorphisms in $\mathrm{AD}$ response. In this regard, the most investigated SNP within this gene is rs6265 which results in a valine to methionine (V66M) substitution (Egan et al., 2003). Nonetheless results are still controversial (Wilkie et al., 2007; Rajewska-Rager et al., 2008; Kang et al., 2009). While some authors found a better outcome for the heterozygote genotype (Yoshida et al., 2007) or a trend in this direction (Tsai et al., 2003; Zou et al., 2010a), on the other hand other studies showed an association between Val/Val genotype and better outcome (Mandelli et al., 2010; Zou et al., 2010b). Moreover, several studies reported Met allele associated with better response (Choi et al., 2006; Licinio et al., 2009), and with lower fluoxetine side effects (Zou et al., 2010a). Rs6265 was also associated with the presence of stressful life events prior to the depression onset (Bukh et al., 2009), although this result was not confirmed in a further study by the same authors (Bukh et al., 2010). Also rs90887, rs61888800, rs7124442, and rs11030104 SNPs within BDNF gene have been associated with AD response (Gratacos et al., 2008; Licinio et al., 2009; Domschke et al., 2010; Mandelli et al., 2010) A strong association was found between rs962369 and an increase in suicidal ideation during AD treatment (Perroud et al., 2009). Finally, it is interesting to note that significant associations between some variants in neurotrophic tyrosine kinase, receptor, type 2 gene (NTRK2) - that encode the BDNF receptor - (rs2289657, rs56142442, rs2289658, rs2289657, and rs2289656) and $\mathrm{AD}$ response have been found in Mexican-Americans (Dong et al., 2009).

\section{OTHER GENE VARIANTS}

Besides those described, there are many genes that may influence both the onset and evolution of MDD, and the effects of $\mathrm{AD}$ pharmacotreatment, among these noteworthy are: the ACE (Baghai et al., 2001, 2003, 2004; Bondy et al., 2005), the CLOCK gene (Benedetti et al., 2003a; Serretti et al., 2003a, 2005b), the glutamatergic system (Laje et al., 2007, 2009; Paddock et al., 2007; Perlis et al., 2009b; Tsunoka et al.,
2009; Horstmann et al., 2010), NOS (Paul, 2001; Suzuki et al., 2003; Wegener et al., 2003; Okumura et al., 2010), and IL-1B (Yu et al., 2003; Tadic et al., 2008; Baune et al., 2010; Uher et al., 2010).

\section{GENOME-WIDE ASSOCIATION STUDIES}

A genome-wide association study (GWAS) is an approach that involves rapidly scanning markers across the complete sets of DNA, or genomes, of many people to find genetic variations associated with a particular disease. This innovative method seems particularly useful to study complex diseases, such as psychiatric disorders. One of the limits of this methodology is the risk of false positive results. Even if in $\mathrm{AD}$ pharmacogenetics, the number of GWAS performed is limited and results need replication, unbiased approaches using genomewide gene expression or association results could lead to important advances in this field. Recently, GWAS were performed within the GENDEP project and the STAR ${ }^{\star}$ D (Craddock et al., 2009; Garriock and Hamilton, 2009; Ising et al., 2009; Laje et al., 2009; Perroud et al., 2010). One of the major limits of GWAS is the incapacity to detect rare genetic variants ( $<1 \%$ of the population). Indeed, current GWAS technologies are able to detect only association for genetic variants present in 5\% or more of the population (Craddock et al., 2009). The results reached by GWAS, to date, have been disappointing. For this reason large meta-analysis to reach genome-wide significance are often needed (McCarthy and Hirschhorn, 2008).

\section{CONCLUSION}

The synopsis of pharmacogenetic studies indicates several strong candidate genes involved in $\mathrm{AD}$ response. Nonetheless, the lack of standardized study design renders meta-analyses as well as comparisons across studies difficult. Several factors can influence the results that often are conflicting: inclusion criteria, medication, outcome and side effect measures, ethnicity, and genetic coverage. Given the complex nature of the biology of $\mathrm{AD}$ treatment response and the relevance of environmental factors, such as repeated treatment, number of episodes or the occurrence of life events, the addition of non-genetic markers for optimal treatment prediction will likely be necessary (Holsboer, 2008). There is great hope that the field of pharmacogenomics will offer personalized medicine treatments based on genetic profiles and in this way may have the potential to offer many benefits for further therapeutic approaches.

\section{REFERENCES}

Acheson, A., Conover, J. C., Fandl, J. P., DeChiara, T. M., Russell, M., Thadani, A., Squinto, S. P., Yancopoulos, G. D., and Lindsay, R. M. (1995). A BDNF autocrine loop in adult sensory neurons prevents cell death. Nature 374, 450-453.

Agid, Y., Buzsaki, G., Diamond, D. M., Frackowiak, R., Giedd J., Girault, J. A., Grace, A., Lambert, J. J., Manji, H., Mayberg, H., Popoli, M., Prochiantz,A., Richter-Levin, G.,Somogyi,P., Spedding, M., Svenningsson, P., and Weinberger, D. (2007). How can drug discovery for psychiatric disorders be improved? Nat. Rev. Drug. Discov. 6, 189-201.
Albert, P. R., and Lemonde, S. (2004). 5-HT1A receptors, gene repression, and depression: guilt by association. Neuroscientist 10, 575-593.

Anttila, S., Kampman, O., Illi,A., Rontu, R., Lehtimaki, T., and Leinonen, E. (2007). Association between 5-HT2A, TPH1 and GNB3 genotypes and response to typical neuroleptics: a serotonergic approach. BMC Psychiatry 7, 22. doi: 10.1186/1471-244X-7-22

Arias, B., Catalan, R., Gasto, C., Gutierrez, B., and Fananas, L. (2003). 5-HTTLPR polymorphism of the serotonin transporter gene predicts non-remission in major depression patients treated with citalopram in a 12-weeks follow up study. J. Clin. Psychopharmacol. 23, 563-567.

Arias, B., Catalan, R., Gasto, C., Gutierrez, B., and Fananas, L. (2005). Evidence for a combined genetic effect of the 5-HT1A receptor and serotonin transporter genes in the clinical outcome of major depressive patients treated with citalopram. J. Psychopharmacol. 19, 166-172.

Arias, B., Serretti, A., Lorenzi, C., Gasto, C., Catalan, R., and Fananas, L. (2006). Analysis of COMT gene (Val 158 Met polymorphism) in the clinical response to SSRIs in depressive patients of European origin. J. Affect. Disord. 90, 251-256.
Baffa, A., Hohoff, C., Baune, B. T., MullerTidow, C., Tidow, N., Freitag, C., Zwanzger, P., Deckert, J., Arolt, V., and Domschke, K. (2010). Norepinephrine and serotonin transporter genes: impact on treatment response in depression. Neuropsychobiology 62, 121-131.

Baghai, T., Schule, C., Zwanzger, P., Zill, P., Ella, R., Eser, D., Deiml, T., Minov, C., Rupprecht, R., and Bondy, B. (2003). Influence of a functional polymorphism within the angiotensin I-converting enzyme gene on partial sleep deprivation in patients with major depression. Neurosci. Lett. 339, 223-226. 
Baghai, T. C., Schule, C., Zill, P., Deiml, T., Eser, D., Zwanzger, P., Ella, R., Rupprecht, R., and Bondy, B. (2004). The angiotensin I converting enzyme insertion/deletion polymorphism influences therapeutic outcome in major depressed women, but not in men. Neurosci. Lett. 363, 38-42.

Baghai, T. C., Schule, C., Zwanzger, P., Minov, C., Schwarz, M. J., de Jonge, S., Rupprecht, R., and Bondy, B. (2001). Possible influence of the insertion/ deletion polymorphism in the angiotensin I-converting enzyme gene on therapeutic outcome in affective disorders. Mol. Psychiatry 6, 258-259.

Ballaz, S. J., Akil, H., and Watson, S. J. (2007). Analysis of 5-HT6 and 5-HT7 receptor gene expression in rats showing differences in novelty-seeking behavior. Neuroscience 147, 428-438.

Barr, C. L., Wigg, K. G., Feng, Y., Zai, G., Malone, M., Roberts, W., Schachar, R., Tannock, R., and Kennedy, J. L. (2000). Attention-deficit hyperactivity disorder and the gene for the dopamine D5 receptor. Mol. Psychiatry 5, 548-551.

Baune, B. T., Dannlowski, U., Domschke, K., Janssen, D. G., Jordan, M. A., Ohrmann, P., Bauer, J., Biros, E., Arolt, V., Kugel, H., Baxter, A. G., and Suslow, T. (2010). The interleukin 1 beta (IL1B) gene is associated with failure to achieve remission and impaired emotion processing in major depression. Biol. Psychiatry 67, 543-549.

Baune, B. T., Hohoff, C., Berger, K., Neumann, A., Mortensen, S., Roehrs, T., Deckert, J., Arolt, V., and Domschke, K. (2008a). Association of the COMT val158met variant with antidepressant treatment response in major depression. Neuropsychopharmacology 33, 924-932.

Baune, B. T., Hohoff, C., Roehrs, T., Deckert, J., Arolt, V., and Domschke, K. (2008b). Serotonin receptor 1A-1019C/G variant: impact on antidepressant pharmacoresponse in melancholic depression? Neurosci. Lett. 436, 111-115.

Bellivier, F., Chaste, P., and Malafosse, A. (2004). Association between the TPH gene $\mathrm{A} 218 \mathrm{C}$ polymorphism and suicidal behavior: a meta-analysis. Am. J. Med. Genet. B Neuropsychiatr. Genet. 124B, 87-91.

Benedetti, F., Colombo, C., Pirovano, A., Marino, E., and Smeraldi, E. (2009). The catechol-O-methyltransferase Val(108/158)Met polymorphism affects antidepressant response to paroxetine in a naturalistic setting. Psychopharmacology (Berl.) 203, 155-160.

Benedetti, F., Serretti, A., Colombo, C., Barbini, B., Lorenzi, C., Campori, E., and Smeraldi, E. (2003a). Influence of CLOCK gene polymorphism on circadian mood fluctuation and illness recurrence in bipolar depression. Am. J. Med. Genet. B Neuropsychiatr. Genet. 123B, 23-26.

Benedetti, F., Serretti, A., Colombo, C., Lilli, R., Lorenzi, C., and Smeraldi, E. (2003b). Dopamine receptor D2 and D3 gene variants are not associated with the antidepressant effect of total sleep deprivation in bipolar depression. Psychiatry Res. 118, 241-247.

Bertilsson, L., Dahl, M., Dalen, P., and Al-Shurbaji, A. (2002). Molecular genetics of CYP2D6: clinical relevance with focus on psychotropic drugs. $B r$. J. Clin. Pharmacol. 53, 111-122.

Bhagwagar, Z., Hinz, R., Taylor, M., Fancy, S., Cowen, P., and Grasby, P. (2006). Increased 5-HT(2A) receptor binding in euthymic, medication-free patients recovered from depression: a positron emission study with [(11)C] MDL 100,907. Am. J. Psychiatry 163, 1580-1587.

Binneman, B., Feltner, D., Kolluri, S., Shi, Y., Qiu, R., and Stiger, T. (2008). A 6-week randomized, placebo-controlled trial of CP-316,311 (a selective CRH1 antagonist) in the treatment of major depression. Am. J. Psychiatry 165, 617-620.

Blendy, J. A. (2006). The role of CREB in depression and antidepressant treatment. Biol. Psychiatry 59, 1144-1150.

Blier, P., and de Montigny, C. (1987). Modification of 5-HT neuron properties by sustained administration of the 5-HT1A agonist gepirone: electrophysiological studies in the rat brain. Synapse 1, 470-480.

Blier, P., and de Montigny, C. (1994). Current advances and trends in the treatment of depression. Trends Pharmacol. Sci. 15, 220-226.

Boer, U., Noll, C., Cierny, I., Krause, D., Hiemke, C., and Knepel, W. (2010). A common mechanism of action of the selective serotonin reuptake inhibitors citalopram and fluoxetine: reversal of chronic psychosocial stress-induced increase in CRE/CREB-directed gene transcription in transgenic reporter gene mice. Eur. J. Pharmacol. 633, 33-38.

Bondy, B., Baghai, T., Zill, P., Schule, C., Eser, D., Deiml, T., Zwanzger, P., Ella, R., and Rupprecht, R. (2005). Genetic variants in the angiotensin I-converting-enzyme (ACE) and angiotensin II receptor (AT1) gene and clinical outcome in depression. Prog. Neuropsychopharmacol. Biol. Psychiatry 29, 1094-1099.

Bonvicini, C., Minelli, A., Scassellati, C., Bortolomasi, M., Segala, M., Sartori, R., Giacopuzzi, M., and Gennarelli, M. (2010). Serotonin transporter gene polymorphisms and treatment-resistant depression.
Prog. Neuropsychopharmacol. Biol. Psychiatry 34, 934-939.

Bozina, N., Peles, A. M., Sagud, M., Bilusic, H., and Jakovljevic, M. (2008). Association study of paroxetine therapeutic response with SERT gene polymorphisms in patients with major depressive disorder. World $J$. Biol. Psychiatry 9, 190-197.

Brady, L. S., Gold, P. W., Herkenham, M., Lynn, A. B., and Whitfield, H. J. Jr. (1992). The antidepressants fluoxetine, idazoxan and phenelzine alter corticotropin-releasing hormone and tyrosine hydroxylase mRNA levels in rat brain: therapeutic implications. Brain Res. 572, 117-125.

Brouwer,J.P.,Appelhof, B.C., van Rossum, E. F., Koper, J. W., Fliers, E., Huyser, J., Schene, A. H., Tijssen, J. G., Van Dyck, R., Lamberts, S. W., Wiersinga, W. M., and Hoogendijk, W. J. (2006). Prediction of treatment response by HPA-axis and glucocorticoid receptor polymorphisms in major depression. Psychoneuroendocrinology 31, 1154-1163.

Bukh, J. D., Bock, C., Vinberg, M., Werge, T., Gether, U., and Kessing, L.V. (2009). Interaction between genetic polymorphisms and stressful life events in first episode depression. J. Affect. Disord. 119, 107-115.

Bukh, J. D., Bock, C., Vinberg, M., Werge, T., Gether, U., and Kessing, L.V. (2010). No interactions between genetic polymorphisms and stressful life events on outcome of antidepressant treatment. Eur. Neuropsychopharmacol. 20, 327-335.

Burcescu, I., Wigg, K., King, N., Vetro, A., Kiss, E., Katay, L., Kennedy, J. L., Kovacs, M., and Barr, C. L. (2005). Association study of CREB1 and childhood-onset mood disorders. Am. J. Med. Genet. B Neuropsychiatr. Genet. 137B, 45-50.

Calabrese, F., Molteni, R., Maj, P. F., Cattaneo, A., Gennarelli, M., Racagni, G., and Riva, M. A. (2007). Chronic duloxetine treatment induces specific changes in the expression of BDNF transcripts and in the subcellular localization of the neurotrophin protein. Neuropsychopharmacology 32, 2351-2359.

Charlier, C., Broly, F., Lhermitte, M., Pinto, E., Ansseau, M., and Plomteux, G. (2003). Polymorphisms in the CYP 2D6 gene: association with plasma concentrations of fluoxetine and paroxetine. Ther. Drug. Monit. 25, 738-742.

Chee, I. S., Lee, S. W., Kim, J. L., Wang, S. K., Shin, Y. O., Shin, S. C., Lee, Y. H., Hwang, H. M., and Lim, M. R. (2001). 5-HT2A receptor gene promoter polymorphism -1438A/G and bipolar disorder. Psychiatr. Genet. 11, 111-114.
Chiou, W. L., Chung, S. M., and Wu, T. C. (2000). Potential role of P-glycoprotein in affecting hepatic metabolism of drugs. Pharm. Res. 17, 903-905.

Choi, M., Kang, R., Ham, B., Jeong, H., and Lee, M. (2005). Serotonin receptor 2A gene polymorphism $(-1438 \mathrm{~A} / \mathrm{G})$ and short-term treatment response to citalopram. Neuropsychobiology 52, 155-162.

Choi, M. J., Kang, R. H., Lim, S. W., Oh, K. S., and Lee, M.S. (2006). Brain-derived neurotrophic factor gene polymorphism (Val66Met) and citalopram response in major depressive disorder. Brain Res. 1118, 176-182.

Choi, M. J., Lee, H. J., Ham, B. J., Cha, J. H., Ryu, S. H., and Lee, M. S. (2004). Association between major depressive disorder and the $-1438 \mathrm{~A} / \mathrm{G}$ polymorphism of the serotonin $2 \mathrm{~A}$ receptor gene. Neuropsychobiology 49, 38-41.

Conti, B., Maier, R., Barr, A. M., Morale, M. C., Lu, X., Sanna, P. P., Bilbe, G., Hoyer, D., and Bartfai, T. (2007). Region-specific transcriptional changes following the three antidepressant treatments electro convulsive therapy, sleep deprivation and fluoxetine. Mol. Psychiatry 12, 167-189.

Coventry, W. L., James, M. R., Eaves, L. J., Gordon, S. D., Gillespie, N. A., Ryan, L., Heath, A. C., Montgomery, G. W., Martin, N. G., and Wray, N. R. (2010). Do5HTTLPR and stressinteract in risk for depression and suicidality? Item response analyses of a large sample. Am. J. Med. Genet. B Neuropsychiatr. Genet. 153B, 757-765.

Craddock, N., Kendler, K., Neale, M. Nurnberger, J., Purcell, S., Rietschel, M., Perlis, R., Santangelo, S. L., Schulze, T. G., Smoller, J. W., and Thapar, A. (2009). Dissecting the phenotype in genome-wide association studies of psychiatric illness. Br. J. Psychiatry 195, 97-99.

Crowley, J. J., Lipsky, R. H., Lucki, I., and Berrettini, W. H. (2008). Variation in the genes encoding vesicular monoamine transporter 2 and beta- 1 adrenergic receptor and antidepressant treatment outcome. Psychiatr. Genet. 18, 248-251.

Cusin, C., Serretti, A., Zanardi, R., Lattuada, E., Rossini, D., Lilli, R., Lorenzi, C., and Smeraldi, E. (2002). Influence of monoamine oxidase A and serotonin receptor $2 \mathrm{~A}$ polymorphisms in SSRIs antidepressant activity. Int. J. Neuropsychopharmacol. 5, 27-35.

De Bellis, M. D., Geracioti, T. D. Jr., Altemus, M., and Kling, M. A. (1993). Cerebrospinal fluid monoamine metabolites in fluoxetine-treated patients with major depression and in healthy volunteers. Biol. Psychiatry $33,636-641$. 
Dogan, O., Yuksel, N., Ergun, M. A., Yilmaz, A., Ilhan, M. N., Karslioglu, H.E., Koc, A., and Menevse, A. (2008). Serotonin transporter gene polymorphisms and sertraline response in major depression patients. Genet. Test. $12,225-231$.

Domschke, K., Lawford, B., Laje, G., Berger, K., Young, R., Morris, P., Deckert, J., Arolt, V., McMahon, F. J., and Baune, B. T. (2010). Brain-derived neurotrophic factor (BDNF) gene: no major impact on antidepressant treatment response. Int. J. Neuropsychopharmacol. 13, 93-101.

Dong, C., Wong, M. L., and Licinio, J. (2009). Sequence variations of ABCB1, SLC6A2, SLC6A3, SLC6A4, CREB1, CRHR1 and NTRK2: association with major depression and antidepressant response in Mexican-Americans. Mol. Psychiatry 14, 1105-1118.

Drago, A., De Ronchi, D., and Serretti, A. (2008). 5-HT1A gene variants and psychiatric disorders: a review of current literature and selection of SNPs for future studies. Int. J. Neuropsychopharmacol. 11, 701-721.

Drago, A., De Ronchi, D., and Serretti, A. (2009). Pharmacogenetics of antidepressant response: an update. Hum. Genomics 3, 257-274.

Durham, L. K., Webb, S. M., Milos, P. M., Clary, C.M., and Seymour,A. B. (2004). The serotonin transporter polymorphism, 5HTTLPR, is associated with a faster response time to sertraline in an elderly population with major depressive disorder. Psychopharmacology (Berl.) 174, 525-529.

Dziedzicka-Wasylewska, M., and Solich, J. (2004). Neuronal cell lines transfected with the dopamine D2 receptor gene promoter as a model for studying the effects of antidepressant drugs. Brain Res. Mol. Brain Res. 128, 75-82.

Egan, M. F., Kojima, M., Callicott, J. H., Goldberg, T. E., Kolachana, B. S., Bertolino, A., Zaitsev, E., Gold, B., Goldman, D., Dean, M., Lu, B., and Weinberger, D. R. (2003). The BDNF val66met polymorphism affects activity-dependent secretion of BDNF and human memory and hippocampal function. Cell 112, 257-269.

Frank, B., Niesler, B., Nothen, M. M., Neidt, H., Propping, P., Bondy, B., Rietschel, M., Maier, W., Albus, M., and Rappold, G. (2004). Investigation of the human serotonin receptor gene HTR3B in bipolar affective and schizophrenic patients. Am. J. Med. Genet. B Neuropsychiatr. Genet. 131B, 1-5.

Fukui, N., Suzuki, Y., Sawamura, K., Sugai, T., Watanabe, J., Inoue, Y., and Someya, T. (2007). Dose-dependent effects of the $3435 \mathrm{C}>\mathrm{T}$ genotype of $A B C B 1$ gene on the steady-state plasma concentration of fluvoxamine in psychiatric patients. Ther. Drug. Monit. 29, 185-189.

Gaikovitch, E. A., Cascorbi, I., Mrozikiewicz, P. M., Brockmoller, J., Frotschl, R., Kopke, K., Gerloff, T., Chernov, J. N., and Roots, I. (2003). Polymorphisms of drug-metabolizing enzymes CYP2C9,CYP2C19,CYP2D6, CYP1A1,NAT2 and of P-glycoprotein in a Russian population. Eur. J. Clin. Pharmacol. 59, 303-312.

Garriock, H. A., Delgado, P., Kling, M. A., Carpenter,L.L., Burke, M., Burke, W.J., Schwartz, T., Marangell, L. B., Husain, M., Erickson, R. P., and Moreno, F. A. (2006). Number of risk genotypes is a risk factor for major depressive disorder: a case control study. Behav. Brain Funct. 2, 24.

Garriock, H.A., and Hamilton, S.P. (2009). Genetic studies of drug response and side effects in the STAR $* D$ study, part 1. J. Clin. Psychiatry 70, 1186-1187.

Gaysina, D., Zainullina, A., Gabdulhakov, R., and Khusnutdinova, E. (2006). The serotonin transporter gene: polymorphism and haplotype analysis in Russian suicide attempters. Neuropsychobiology 54, 70-74.

Gex-Fabry, M., Eap, C. B., Oneda, B., Gervasoni, N., Aubry, J. M., Bondolfi, G., and Bertschy, G. (2008). CYP2D6 and $A B C B 1$ genetic variability: influence on paroxetine plasma level and therapeutic response. Ther. Drug. Monit. 30, 474-482.

Gold, P. W., and Chrousos, G. P. (2002). Organization of the stress system and its dysregulation in melancholic and atypical depression: high vs low CRH/NE states. Mol. Psychiatry 7, 254-275.

Gottesman, I. I., and Gould, T. D. (2003). The endophenotype concept in psychiatry: etymology and strategic intentions. Am. J. Psychiatry 160, 636-645.

Grasmader, K., Verwohlt, P. L., Rietschel, M., Dragicevic, A., Muller, M., Hiemke, C., Freymann, N., Zobel, A., Maier, W., and Rao, M. L. (2004). Impact of polymorphisms of cytochromeP450 isoenzymes 2C9, 2C19 and 2D6 on plasma concentrations and clinical effects of antidepressants in a naturalistic clinical setting. Eur. J. Clin. Pharmacol. 60, 329-336.

Gratacos, M., Soria, V., Urretavizcaya, M., Gonzalez,J.R., Crespo, J.M., Bayes, M., de Cid, R., Menchon, J. M., Vallejo, J., and Estivill, X. (2008). A brain-derived neurotrophic factor (BDNF) haplotype is associated with antidepressant treatment outcome in mood disorders. Pharmacogenomics J. 8, 101-112.

Greenwood, T. A., Alexander, M., Keck, P. E., McElroy, S., Sadovnick, A. D., Remick, R. A., and Kelsoe, J. R. (2001). Evidence for linkage disequilibrium between the dopamine transporter and bipolar disorder. Am. J. Med. Genet. 105, 145-151.

Gutierrez, B., Pintor,L., Gasto, C., Rosa,A., Bertranpetit, J., Vieta, E., and Fananas, L. (1998). Variability in the serotonin transporter gene and increased risk for major depression with melancholia. Hum. Genet. 103, 319-322.

Haefner, S., Baghai, T. C., Schule, C., Eser, D., Spraul, M., Zill, P., Rupprecht, R., and Bondy, B. (2008). Impact of gene-gender effects of adrenergic polymorphisms on hypothalamicpituitary-adrenal axis activity in depressed patients. Neuropsychobiology $58,154-162$.

Hahn, M. K., Mazei-Robison, M. S., and Blakely, R. D. (2005). Single nucleotide polymorphisms in the human norepinephrine transporter gene affect expression, trafficking, antidepressant interaction, and protein kinase $\mathrm{C}$ regulation. Mol. Pharmacol. 68, 457-466.

Ham, B., Lee, M., Lee, H., Kang, R., Han, C., Choi, M., Lee, S., and Ryu, S. (2005). No association between the tryptophan hydroxylase gene polymorphism and major depressive disorders and antidepressant response in a Korean population. Psychiatr. Genet. 15, 229-301.

Ham, B. J., Lee, B. C., Paik, J. W., Kang, R. H., Choi, M. J., Choi, I. G., and Lee, M. S. (2007). Association between the tryptophan hydroxylase-1 gene A218C polymorphism and citalopram antidepressant response in a Korean population. Prog. Neuropsychopharmacol. Biol. Psychiatry 31, 104-107.

Hamm, H. E. (1998). The many faces of G protein signaling.J. Biol. Chem. 273, 669-672.

Heils, A., Teufel, A., Petri, S., Stöber, G., Riederer, P., Bengel, D., and Lesch, P. (1996). Allelic variation of human serotonin trasporter gene expression. J. Neurochem. 66, 2621-2624.

Heinz, A., Goldman, D., Gallinat, J., Schumann, G., and Puls, I. (2004). Pharmacogeneticinsights to monoaminergic dysfunction in alcohol dependence. Psychopharmacology (Berl.) 174, 561-570.

Hettema, J. M., An, S. S., van den Oord, E. J., Neale, M. C., Kendler, K. S., and Chen, X. (2009). Association study of CREB1 with major depressive disorder and related phenotypes. Am. J. Med. Genet. B Neuropsychiatr. Genet. 150B, 1128-1132.

Higuchi, H. (2010). Prediction of antidepressant response to milnacipran and fluvoxamine using pharmacogenetical methods. Nihon Shinkei Seishin Yakurigaku Zasshi 30, 71-76.

Hilli, J., Heikkinen, T., Rontu, R., Lehtimaki, T., Kishida, I., Aklillu, E., Bertilsson, L., Vahlberg, T., and Laine,
K. (2009). MAO-A and COMT genotypes as possible regulators of perinatal serotonergic symptoms after in utero exposure to SSRIs. Eur. Neuropsychopharmacol. 19, 363-370.

Hjorth, S., and Sharp, T. (1991). Effect of the 5-HT1A receptor agonist 8-OH-DPAT on the release of 5-HT in dorsal and median raphe-innervated rat brain regions as measured by in vivo microdialysis. Life Sci. 48 , 1779-1786.

Hoffmeyer, S., Burk, O., von Richter, O., Arnold, H. P., Brockmoller, J., Johne, A., Cascorbi, I., Gerloff, T., Roots, I., Eichelbaum, M., and Brinkmann, U. (2000). Functional polymorphisms of the human multidrug-resistance gene: multiple sequence variations and correlation of one allele with P-glycoprotein expression and activity in vivo. Proc. Natl. Acad. Sci. U.S.A. 97, 3473-3478.

Holsboer, F. (2008). How can we realize the promise of personalized antidepressant medicines? Nat. Rev. Neurosci. 9, 638-646.

Hong, C. J., Chen, T. J., Yu, Y. W., and Tsai, S. J. (2006). Response to fluoxetine and serotonin $1 \mathrm{~A}$ receptor (C-1019G) polymorphism in Taiwan Chinese major depressive disorder. Pharmacogenomics J. 6, 27-33.

Horstmann, S., and Binder, E. B. (2009). Pharmacogenomics of antidepressant drugs. Pharmacol. Ther. 124, 57-73.

Horstmann, S., Lucae, S., Menke, A., Hennings, J. M., Ising, M., Roeske, D., Muller-Myhsok, B., Holsboer, F., and Binder, E. B. (2010). Polymorphisms in GRIK4, HTR2A, and FKBP5 show interactive effects in predicting remission to antidepressant treatment. Neuropsychopharmacology 35, 727-740.

Hranilovic, D., Stefulj, J., Schwab, S., Borrmann-Hassenbach, M., Albus, M., Jernej, B., and Wildenauer, D. (2004). Serotonin transporter promoter and intron 2 polymorphisms: relationship between allelic variants and gene expression. Biol. Psychiatry 55, 1090-1094.

Hu, X.Z., Rush, A. J., Charney, D., Wilson, A. F., Sorant, A. J., Papanicolaou, G. J., Fava, M., Trivedi, M. H., Wisniewski, S. R., Laje, G., Paddock, S., McMahon, F. J., Manji, H., and Lipsky, R. H. (2007). Association between a functional serotonin transporter promoter polymorphism and citalopram treatment in adult outpatients with major depression. Arch. Gen. Psychiatry 64, 783-792.

Huezo-Diaz, P., Uher, R., Smith, R., Rietschel,M., Henigsberg, N., Marusic, A., Mors, O., Maier, W., Hauser, J., Souery, D., Placentino, A., Zobel, A., Larsen, E. R., Czerski, P. M., Gupta, 
B., Hoda, F., Perroud, N., Farmer, A., Craig, I., Aitchison, K. J., and McGuffin, P. (2009). Moderation of antidepressant response by the serotonin transporter gene. Br. J. Psychiatry 195, 30-38.

Hutson, P. H., Sarna, G. S., O'Connell, M. T., and Curzon, G. (1989). Hippocampal 5-HT synthesis and release in vivo is decreased by infusion of 8-OHDPAT into the nucleus raphe dorsalis. Neurosci. Lett. 100, 276-280.

Ichikawa, J., and Meltzer, H. Y. (1995). Effect of antidepressants on striatal and accumbens extracellular dopamine levels. Eur. J. Pharmacol. 281, 255-261.

Illi, A., Poutanen, O., Setala-Soikkeli, E., Kampman, O., Viikki, M., Huhtala, H., Mononen, N., Haraldsson, S., Koivisto, P. A., Leinonen, E., and Lehtimaki, T. (2010). Is 5-HTTLPR linked to the response of selective serotonin reuptake inhibitors in MDD? Eur. Arch. Psychiatry Clin. Neurosci. doi: 10.1007/s00406-010-0126-x. [Epub ahead of print].

Illi, A., Setala-Soikkeli, E., Viikki, M., Poutanen, O., Huhtala, H., Mononen, N., Lehtimaki, T., Leinonen, E., and Kampman, O. (2009). 5-HTR1A, 5-HTR2A, 5-HTR6, TPH1 and TPH2 polymorphisms and major depression. Neuroreport 20, 1125-1128.

Ingelman-Sundberg, M., Sim, S. C., Gomez,A., and Rodriguez-Antona, C. (2007). Influence of cytochrome P450 polymorphisms on drug therapies: pharmacogenetic, pharmacoepigenetic and clinical aspects. Pharmacol. Ther. 116, 496-526.

Ising, M., and Holsboer, F. (2007). CRHsub-1 receptor antagonists for the treatment of depression and anxiety. Exp. Clin. Psychopharmacol. 15, 519-528.

Ising, M., Kunzel, H. E., Binder, E. B., Nickel, T., Modell, S., and Holsboer, F. (2005). The combined dexamethasone/CRH test as a potential surrogate marker in depression. Prog. Neuropsychopharmacol. Biol. Psychiatry 29, 1085-1093.

Ising, M., Lucae, S., Binder, E. B., Bettecken, T., Uhr, M., Ripke, S., Kohli, M. A., Hennings, J. M., Horstmann, S., Kloiber, S., Menke, A., Bondy, B., Rupprecht, R., Domschke, K., Baune, B. T., Arolt, V., Rush, A. J., Holsboer, F., and Muller-Myhsok, B. (2009). A genomewide association study points to multiple loci that predict antidepressant drug treatment outcome in depression. Arch. Gen. Psychiatry 66, 966-975.

Ito, K., Yoshida, K., Sato, K., Takahashi, H., Kamata, M., Higuchi, H., Shimizu, T., Itoh, K., Inoue, K., Tezuka, T., Suzuki,
T., Ohkubo, T., Sugawara, K., and Otani, K. (2002). A variable number of tandem repeats in the serotonin transporter gene does not affect the antidepressant response to fluvoxamine. Psychiatry Res. 111, 235-239.

Ito, S., Ieiri, I., Tanabe, M., Suzuki, A., Higuchi, S., and Otsubo, K. (2001). Polymorphism of the ABC transporter genes, MDR1, MRP1 and MRP2/ cMOAT, in healthy Japanese subjects. Pharmacogenetics 11, 175-184.

Jacobsen, J. P., and Mork, A. (2004). The effect of escitalopram, desipramine, electroconvulsive seizures and lithium on brain-derived neurotrophic factor mRNA and protein expression in the rat brain and the correlation to $5-\mathrm{HT}$ and 5-HIAA levels. Brain Res. 1024, 183-192.

Jonsson, E. G., Nothen, M. M., Gustavsson, J. P., Neidt, H., Bunzel, R., Propping, P., and Sedvall, G. C. (1998). Polymorphisms in the dopamine, serotonin, and norepinephrine transporter genes and their relationships to monoamine metabolite concentrations in CSF of healthy volunteers. Psychiatry Res. 79, 1-9.

Joyce, P. R., Mulder, R. T., Luty, S. E., McKenzie, J. M., Miller, A. L., Rogers, G. R., and Kennedy, M. A. (2003). Age-dependent antidepressant pharmacogenomics: polymorphisms of the serotonin transporter and $G$ protein beta 3 subunit as predictors of response to fluoxetine and nortriptyline. Int. J. Neuropsychopharmacol. 6, 339-346.

Kang, R., Chang, H., Wong, M., Choi, M., Park, J., Lee, H., Jung, I., Joe, S., Kim, L., Kim, S., Kim, Y., Han, C., Ham, B., Lee, H., Ko, Y., and Lee, M. (2009). Brain-derived neurotrophic factor gene polymorphisms and mirtazapine responses in Koreans with major depression. J Psychopharmacol. 24, 1755-1763.

Kang, R. H., Hahn, S. W., Choi, M. J., and Lee, M. S. (2007). Relationship between G-protein beta-3 subunit C825T polymorphism and mirtazapine responses in Korean patients with major depression. Neuropsychobiology $56,1-5$.

Kato, M., Fukuda, T., Serretti, A., Wakeno, M., Okugawa, G., Ikenaga, Y., Hosoi, Y., Takekita,Y.,Mandelli,L.,Azuma, J., and Kinoshita, T. (2008a). ABCB1 (MDR1) gene polymorphisms are associated with the clinical response to paroxetine in patients with major depressive disorder.Prog. Neuropsychopharmacol. Biol. Psychiatry 32, 398-404.

Kato, M., Wakeno, M., Okugawa, G., Fukuda, T., Takekita, Y., Hosoi, Y., Azuma, J., Kinoshita, T., and Serretti, A. (2008b). Antidepressant response and intolerance to SSRI is not influenced by G-protein beta3 subunit gene C825T polymorphism in Japanese major depressive patients. Prog. Neuropsychopharmacol. Biol. Psychiatry 32, 1041-1044.

Kato, M., Fukuda, T., Wakeno, M., Fukuda, K., Okugawa, G., Ikenaga, Y., Yamashita, M., Takekita, Y., Nobuhara, K.,Azuma, J., and Kinoshita, T. (2006). Effects of the serotonin type $2 \mathrm{~A}, 3 \mathrm{~A}$ and $3 \mathrm{~B}$ receptor and the serotonin transporter genes on paroxetine and fluvoxamine efficacy and adverse drug reactions in depressed Japanese patients. Neuropsychobiology 53, 186-195.

Kato, M., Fukuda, T., Wakeno, M., Okugawa, G., Takekita, Y., Watanabe, S., Yamashita, M., Hosoi, Y., Azuma, J., Kinoshita, T., and Serretti, A. (2009). Effect of 5-HT1A gene polymorphisms on antidepressant response in major depressive disorder. Am. J. Med. Genet. B Neuropsychiatr. Genet. 150B, 115-123.

Kato, M., Wakeno, M., Okugawa, G., Fukuda, T., Azuma, J., Kinoshita, T., and Serretti, A. (2007). No association of TPH1 218A/C polymorphism with treatment response and intolerance to SSRIs in Japanese patients with major depression. Neuropsychobiology 56, 167-171.

Keers, R., Bonvicini, C., Scassellati, C. Uher, R., Placentino, A., Giovannini, C., Rietschel, M., Henigsberg, N., Kozel, D. Mors, O., Maier, W., Hauser, J., Souery, D., Mendlewicz, J., Schmal, C., Zobel, A., Larsen, E. R., Szczepankiewicz, A., Kovacic, Z., Elkin, A., Craig, I., McGuffin, P., Farmer, A. E., Aitchison, K. J., and Gennarelli, M. (2010a). Variation in GNB3 predicts response and adverse reactions to antidepressants. J. Psychopharmacol. doi: 10.1177/0269881110376683. [Epub ahead of print].

Keers, R., Uher, R., Huezo-Diaz, P., Smith, R., Jaffee, S., Rietschel, M., Henigsberg, N., Kozel, D., Mors, O., Maier, W., Zobel, A., Hauser, J., Souery, D., Placentino, A., Larsen, E. R., Dmitrzak-Weglarz, M., Gupta, B., Hoda, F., Craig, I., McGuffin, P., Farmer, A. E., and Aitchison, K. J. (2010b). Interaction between serotonin transporter gene variants and life events predicts response to antidepressants in the GENDEP project. Pharmacogenomics J. doi: 10.1038/ tpj.2010.14. [Epub ahead of print].

Kehne, J. H. (2007). The CRF1 receptor, a novel target for the treatment of depression, anxiety, and stress-related disorders. CNS Neurol. Disord. Drug Targets 6, 163-182.

Kim, D. K., Lim, S. W., Lee, S., Sohn, S. E., Kim, S., Hahn, C. G., and Carroll, B. J. (2000). Serotonin transporter gene polymorphism and antidepressant response. Neuroreport 11, 215-219.

Kim, H., Lim, S. W., Kim, S., Kim, J. W., Chang, Y. H., Carroll, B. J., and Kim, D. K. (2006). Monoamine transporter gene polymorphisms and antidepressant response in Koreans with late-life depression. JAMA 296, 1609-1618.

Kioka, N., Tsubota, J., Kakehi, Y., Komano, T., Gottesman, M. M., Pastan, I., and Ueda, K. (1989). P-glycoprotein gene (MDR1) cDNA from human adrenal: normal P-glycoprotein carries Gly185 with an altered pattern of multidrug resistance. Biochem. Biophys. Res. Commun. 162, 224-231.

Kirchheiner, J., Nickchen, K., Sasse, J., Bauer, M., Roots, I., and Brockmoller, J. (2006). A 40-basepair VNTR polymorphism in the dopamine transporter (DAT1) gene and the rapid response to antidepressant treatment. Pharmacogenomics J. 7, 48-55.

Kishi, T., Yoshimura, R., Kitajima, T., Okochi, T., Okumura, T., Tsunoka, T., Yamanouchi, Y., Kinoshita, Y., Kawashima, K., Naitoh, H., Nakamura, J., Ozaki, N., and Iwata, N. (2010). HTR2A is associated with SSRI response in major depressive disorder in a Japanese cohort. Neuromol. Med. 12, 237-242.

Kocabas, N. A., Faghel, C., Barreto, M., Kasper, S., Linotte, S., Mendlewicz, J., Noro, M., Oswald, P., Souery, D., Zohar, J., and Massat, I. (2010). The impact of catechol-O-methyltransferase SNPs and haplotypes on treatment response phenotypes in major depressive disorder: a case-control association study. Int. Clin. Psychopharmacol. 25, 218-227.

Kohen, R., Metcalf, M. A., Khan, N., Druck, T., Huebner, K., Lachowicz, J. E., Meltzer, H. Y., Sibley, D. R., Roth, B. L., and Hamblin, M. W. (1996). Cloning, characterization, and chromosomal localization of a human 5-HT6 serotonin receptor. J. Neurochem. 66, 47-56.

Kraft, J., Slager, S., McGrath, P., and Hamilton, S. (2005). Sequence analysis of the serotonin transporter and associations with antidepressant response. Biol. Psychiatry 58, 374-381.

Kraft, J. B., Peters, E. J., Slager, S. L., Jenkins, G. D., Reinalda, M. S., McGrath, P. J., and Hamilton, S. P. (2007). Analysis of association between the serotonin transporter and antidepressant response in a large clinical sample. Biol. Psychiatry 61, 734-742.

Kreiss, D. S., and Lucki, I. (1994). Differential regulation of serotonin (5-HT) release in the striatum and hippocampus by 5-HT1A autoreceptors of the dorsal and median raphe nuclei. J. Pharmacol. Exp. Ther. 269, 1268-1279. 
Kugaya, A., Seneca, N. M., Snyder, P. J., Williams, S. A., Malison, R. T., Baldwin, R. M., Seibyl, J. P., and Innis, R. B. (2003). Changes in human in vivo serotonin and dopamine transporter availabilities during chronic antidepressant administration. Neuropsychopharmacology 28, 413-420.

Kuipers, S. D., Trentani, A., Westenbroek, C., Bramham, C. R., Korf, J., Kema, I. P., Ter Horst, G. J., and Den Boer, J. A. (2006). Unique patterns of FOS, phospho-CREB and BrdU immunoreactivity in the female rat brain following chronic stress and citalopram treatment. Neuropharmacology 50, 428-440.

Kusuhara, H., Suzuki, H., and Sugiyama, Y. (1998). The role of P-glycoprotein and canalicular multispecific organic anion transporter in the hepatobiliary excretion of drugs. J. Pharm. Sci. 87, 1025-1040.

Lachman, H. M., Papolos, D. F., Saito, T., Yu, Y. M., Szumlanski, C. L., and Weinshilboum, R. M. (1996). Human catechol-O-methyltransferase pharmacogenetics: description of a functional polymorphism and its potential application to neuropsychiatric disorders. Pharmacogenetics 6, 243-250.

Laika, B., Leucht, S., and Steimer, W. (2006). ABCB1 (P-glycoprotein/ MDR1) gene G2677T/a sequence variation (polymorphism): lack of association with side effects and therapeutic response in depressed inpatients treated with amitriptyline. Clin. Chem. 52, 893-895.

Laje, G., Paddock, S., Manji, H., Rush, A. J., Wilson, A. F., Charney, D., and McMahon, F. J. (2007). Genetic markers of suicidal ideation emerging during citalopram treatment of major depression. Am. J. Psychiatry 164, 1530-1538.

Laje, G., Perlis, R. H., Rush, A. J., and McMahon, F. J. (2009). Pharmacogenetics studies in STAR ${ }^{\star} \mathrm{D}$ : strengths, limitations, and results. Psychiatr. Serv. 60, 1446-1457.

Lavretsky, H., Siddarth, P., Kumar, A., and Reynolds, C. F. III. (2008). The effects of the dopamine and serotonin transporter polymorphisms on clinical features and treatment response in geriatric depression: a pilot study. Int. J. Geriatr. Psychiatry 23, 55-59.

Lee, H., Kang, R., Han, S., Paik, J., Chang, H., Jeong, Y., and Lee, M. (2009). Association of glucocorticoid receptor polymorphisms with the susceptibility to major depressive disorder and treatment responses in Korean depressive patients. Acta Neuropsychiatr. 21, 11-17.

Lee, H. J., Cha, J. H., Ham, B. J., Han, C. S., Kim, Y. K., Lee, S. H., Ryu, S. H., Kang,
R.H., Choi, M. J., and Lee, M.S. (2004). Association between a G-protein beta3 subunit gene polymorphism and the symptomatology and treatment responses of major depressive disorders. Pharmacogenomics J. 4, 29-33.

Lee, S., Lee, K., Lee, H., Ham, B., Ryu, S., and Lee, M. (2005). Association between the 5-HT6 receptor C267T polymorphism and response to antidepressant treatment in major depressive disorder. Psychiatry Clin. Neurosci. 59, 140-145.

Lemonde, S., Du, L., Bakish, D., Hrdina, P., and Albert, P. R. (2004). Association of the C(1019)G 5-HT1A functional promoter polymorphism with antidepressant response. Psychopharmacology (Berl.) 24, 24.

Lemonde, S., Turecki, G., Bakish, D., Du, L., Hrdina, P., Bown, C., Sequeira, A., Kushwaha, N., Morris, S., Basak, A., Ou, X., and Albert, P. (2003). Impaired trans-repression at a 5-HT1A receptor gene polymorphism associated with major depression and suicide. J. Neurosci. 23, 8788-8799.

Lesch, K. P., and Gutknecht, L. (2004). Focus on The 5-HT1A receptor:emerging role of a gene regulatory variant in psychopathology and pharmacogenetics. Int. J. Neuropsychopharmacol. 7, 381-385.

Leszczynska-Rodziewicz, A., Czerski, P. M., Kapelski, P., Godlewski, S., Dmitrzak-Weglarz, M., Rybakowski, J., and Hauser, J. (2002). A polymorphism of the norepinephrine transporter gene in bipolar disorder and schizophrenia: lack of association. Neuropsychobiology 45, 182-185.

Leuchter,A. F., McCracken, J. T., Hunter, A. M., Cook, I. A., and Alpert, J. E. (2009). Monoamine oxidase a and catechol$\mathrm{O}$-methyltransferase functional polymorphisms and the placebo response in major depressive disorder. J. Clin. Psychopharmacol. 29, 372-377.

Levin, G. M., Bowles, T. M., Ehret, M. J., Langaee, T., Tan, J. Y., Johnson, J. A., and Millard, W. J. (2007). Assessment of human serotonin 1 A receptor polymorphisms and SSRI responsiveness. Mol. Diagn. Ther. 11, 155-160.

Licinio, J., Dong, C., and Wong, M. L. (2009). Novel sequence variations in the brain-derived neurotrophic factor gene and association with major depression and antidepressant treatment response. Arch. Gen. Psychiatry 66, 488-497.

Licinio, J., O'Kirwan, F., Irizarry, K., Merriman, B., Thakur, S., Jepson, R., Lake, S., Tantisira, K., Weiss, S., and Wong, M. (2004). Association of a corticotropin-releasing hormone receptor 1 haplotype and antidepressant treatment response in Mexican-Americans. Mol. Psychiatry 9, 1075-1082.
Lin, E., Chen, P. S., Chang, H. H., Gean, P. W., Tsai, H. C., Yang, Y. K., and Lu, R. B. (2009). Interaction of serotonin-related genes affects short-term antidepressant response in major depressive disorder. Prog. Neuropsychopharmacol. Biol. Psychiatry 33, 1167-1172.

Lin, J. H., and Lu, A. Y. (1998). Inhibition and induction of cytochrome P450 and the clinical implications. Clin. Pharmacokinet. 35, 361-390.

Liu, Z., Zhu, F., Wang, G., Xiao, Z., Tang, J., Liu, W., Wang, H., Liu, H., Wang, X., Wu, Y., Cao, Z., and Li, W. (2007). Association study of corticotropinreleasing hormone receptor 1 gene polymorphisms and antidepressant response in major depressive disorders. Neurosci. Lett. 414, 155-158.

Liu, Z. C., Luo, X. N., and Wang, G. H. (2002a). Corticotropin-releasing factor and major depression. Foreign Med. Sci. Sect. Psychiatry 2, 156-158.

Liu, Z. Q., Tan, Z. R., Wang, D., Huang, S. L., Wang, L. S., and Zhou, H. H. (2002b). Simultaneous determination of fluoxetine and its metabolite p-trifluoromethylphenol in human liver microsomes using a gas chromatographic-electron-capture detection procedure. J. Chromatogr. B Analyt. Technol. Biomed. Life Sci. 769, 305-311.

Lopez de Lara, C., Dumais, A., Rouleau, G., Lesage, A., Dumont, M., Chawky, N., Alda, M., Benkelfat, C., and Turecki, G. (2006). STin 2 variant and family history of suicide as significant predictors of suicide completion in major depression. Biol. Psychiatry 59, 114-120.

Lucae, S., Ising, M., Horstmann, S., Baune, B. T., Arolt, V., Muller-Myhsok, B., Holsboer, F., and Domschke, K. (2010). HTR2A gene variation is involved in antidepressant treatment response. Eur. Neuropsychopharmacol. 20, 65-68.

MacKenzie, A., and Quinn, J. (1999). A serotonin transporter gene intron 2 polymorphic region, correlated with affective disorders, has allele-dependent differential enhancer-like properties in the mouse embryo. Proc. Natl. Acad. Sci. U.S.A. 96, 15251-15255.

Maj, J., Rogoz,Z., Skuza, G., and Sowinska H. (1989). The effect of repeated administration of imipramine, citalopram and mianserin on responsiveness of central serotonergic, alpha 2-adrenergic and cholinergic system in mice. Pol. J. Pharmacol. Pharm. 41, 313-319.

Malhotra, A. K., Murphy, G. M. Jr., and Kennedy,J.L.(2004).Pharmacogenetics of psychotropic drug response. Am. J. Psychiatry 161, 780-796.

Mamdani, F., Alda, M., Grof, P., Young, L. T., Rouleau, G., and Turecki, G. (2008). Lithium response and genetic variation in the CREB family of genes. Am.
J.Med. Genet. B Neuropsychiatr. Genet. 147B, 500-504.

Mandelli, L., Marino, E., Pirovano, A., Calati, R., Zanardi, R., Colombo, C., and Serretti, A. (2009). Interaction between SERTPR and stressful life events on response to antidepressant treatment.Eur. Neuropsychopharmacol. 19, 64-67.

Mandelli, L., Mazza, M., Martinotti, G., Tavian, D., Colombo, E., Missaglia, S., Di Nicola, M., De Ronchi, D., Negri, G., Colombo, R., Janiri, L., Serretti, A. (2010). Further evidence supporting the influence of brain-derived neurotrophic factor on the outcome of bipolar depression: independent effect of brain-derived neurotrophic factor and harm avoidance. J. Psychopharmacol. 24, 1747-1754.

Mandelli, L., Serretti, A., Marino, E., Pirovano, A., Calati, R., and Colombo, C. (2007). Interaction between serotonin transporter gene, catechol- $O$ methyltransferase gene and stressful life events in mood disorders. Int. J. Neuropsychopharmacol. 10, 437-447.

Maron, E., Tammiste, A., Kallassalu, K., Eller, T., Vasar, V., Nutt, D. J., and Metspalu, A. (2009). Serotonin transporter promoter region polymorphisms do not influence treatment response to escitalopram in patients with major depression. Eur. Neuropsychopharmacol. 19, 451-456.

Mathers, C. D., Vos, E. T., Stevenson, C. E., and Begg, S. J. (2000). The Australian Burden of Disease Study: measuring the loss of health from diseases, injuries and risk factors. Med. J. Aust. 172, 592-596.

McCarthy, M. I., and Hirschhorn, J. N. (2008). Genome-wide association studies: past, present and future. Hum. Mol. Genet. 17, R100-R101.

McMahon, F. J., Buervenich, S., Charney, D., Lipsky, R., Rush, A. J., Wilson, A. F., Sorant, A. J., Papanicolaou, G. J., Laje, G., Fava, M., Trivedi, M.H.,Wisniewski, S. R., and Manji, H. (2006). Variation in the gene encoding the serotonin $2 \mathrm{~A}$ receptor is associated with outcome of antidepressant treatment. Am. J. Hum. Genet. 78, 804-814.

Meller, E., Goldstein, M., and Bohmaker, K. (1990). Receptor reserve for 5-hydroxytryptamine1A-mediated inhibition of serotonin synthesis: possible relationship to anxiolytic properties of 5-hydroxytryptaminelA agonists. Mol. Pharmacol. 37, 231-237.

Meyer, J. H., Kapur, S., Eisfeld, B., Brown, G. M., Houle, S., DaSilva, J., Wilson, A. A., Rafi-Tari, S., Mayberg, H. S., and Kennedy, S. H. (2001). The effect of paroxetine on 5-HT2A receptors in depression: an [18F]setoperone PET imaging study. Am. J. Psychiatry 158, 78-85. 
Michelson, D., Galliven, E., Hill, L., Demitrack, M., Chrousos, G., and Gold, P. (1997). Chronic imipramine is associated with diminished hypothalamic-pituitary-adrenal axis responsivity in healthy humans. J. Clin. Endocrinol. Metab. 82, 2601-2606.

Mickley, L. A., Lee, J. S., Weng, Z., Zhan, Z., Alvarez, M., Wilson, W., Bates, S. E., and Fojo, T. (1998). Genetic polymorphism in MDR-1: a tool for examining allelic expression in normal cells, unselected and drug-selected cell lines, and human tumors. Blood 91, 1749-1756.

Mihaljevic Peles, A., Bozina, N., Sagud, M., Rojnic Kuzman, M., and Lovric, M. (2008). MDR1 gene polymorphism: therapeutic response to paroxetine among patients with major depression. Prog. Neuropsychopharmacol. Biol. Psychiatry 32, 1439-1444.

Min, W., Li, T., Ma, X., Li, Z., Yu, T., Gao, D., Zhang, B., Yun, Y., and Sun, X. (2009). Monoamine transporter gene polymorphisms affect susceptibility to depression and predict antidepressant response. Psychopharmacology (Berl.) 205, 409-417.

Minov, C., Baghai, T. C., Schule, C., Zwanzger, P., Schwarz, M. J., Zill, P., Rupprecht, R., and Bondy, B. (2001). Serotonin-2A-receptor and -transporter polymorphisms: lack of association in patients with major depression. Neurosci. Lett. 303, 119-122.

Mitchell, E. S., Sexton, T., and Neumaier, J. F. (2007). Increased expression of 5-HT6 receptors in the rat dorsomedial striatum impairs instrumental learning. Neuropsychopharmacology 32, 1520-1530.

Mrazek, D. A., Rush, A. J., Biernacka, J. M., O’Kane, D. J., Cunningham, J. M., Wieben, E. D., Schaid, D. J., Drews, M. S., Courson, V. L., Snyder, K. A., Black, J. L. III., and Weinshilboum, R. M. (2009). SLC6A4 variation and citalopram response. Am. J. Med. Genet. B Neuropsychiatr. Genet. 150B, 341-351.

Muller, D. J., Schulze, T. G., Macciardi, F., Ohlraun, S., Gross, M. M., Scherk, H., Neidt, H., Syagailo, Y. V., Grassle, M., Nothen, M. M., Maier, W., Lesch, K. P., and Rietschel,M. (2002). Moclobemide response in depressed patients: association study with a functional polymorphism in the monoamine oxidase A promoter. Pharmacopsychiatry 35, 157-158.

Murata, Y., Kobayashi, D., Imuta, N., Haraguchi, K., Ieiri, I., Nishimura, R., Koyama, S., and Mine, K. (2010). Effects of the serotonin 1A, 2A, 2C, 3A, and $3 \mathrm{~B}$ and serotonin transporter gene polymorphisms on the occurrence of paroxetine discontinuation syndrome. J. Clin. Psychopharmacol. 30, 11-17.
Murphy, G. M. Jr., Hollander, S. B., Rodrigues, H. E., Kremer, C., and Schatzberg, A. F. (2004). Effects of the serotonin transporter gene promoter polymorphism on mirtazapine and paroxetine efficacy and adverse events in geriatric major depression. Arch. Gen. Psychiatry 61, 1163-1169.

Murphy, G. M. Jr., Kremer, C., Rodrigues, H. E., and Schatzberg, A. F. (2003). Pharmacogenetics of antidepressant medication intolerance. Am. J. Psychiatry 160, 1830-1835.

Murray, C. J., and Lopez, A. D. (1997). Alternative projections of mortality and disability by cause 1990-2020: Global Burden of Disease Study. Lancet 349, 1498-1504.

Nemeroff, C. B., Owens, M. J., Bissette, G., Andorn, A. C., and Stanley, M. (1988). Reduced corticotropin releasing factor binding sites in the frontal cortex of suicide victims. Arch. Gen. Psychiatry 45, 577-579.

Nemeroff, C. B., Widerlov, E., Bissette, G., Walleus, H., Karlsson, I., Eklund, K., Kilts, C. D., Loosen, P. T., and Vale, W. (1984). Elevated concentrations of CSF corticotropin-releasing factorlike immunoreactivity in depressed patients. Science 226, 1342-1344.

Niesler, B., Flohr, T., Nothen, M. M., Fischer, C., Rietschel, M., Franzek, E., Albus, M., Propping, P., and Rappold, G. A. (2001). Association between the 5'UTR variant C178T of the serotonin receptor gene HTR3A and bipolar affective disorder. Pharmacogenetics 11, 471-475.

Nikisch, G., Eap, C. B., and Baumann, P. (2008). Citalopram enantiomers in plasma and cerebrospinal fluid of ABCB1 genotyped depressive patients and clinical response: a pilot study. Pharmacol. Res. 58, 344-347.

Noro, M., Antonijevic, I., Forray, C., and Kasper, S., Kocabas, N. A., Lecrubier, Y., Linotte, S., Mendlewicz, J., Montgomery, S., Snyder, L., Souery, D., Verbanck, P., Zohar, J., and Massat, I. (2010). 5HT1A and 5HT2A receptor genes in treatment response phenotypes in major depressive disorder. Int. Clin. Psychopharmacol. 25, 228-231.

Ogilvie, A. D., Battersby, S., Bubb, V. J., Fink, G., Harmar, A. J., Goodwin, G. M., and Smith, C. A. D. (1996). Polymorphism in serotonin transporter gene associated with susceptibility to major depression. Lancet 347, 731-733.

Ohara, K., Tanabu, S., Ishibashi, K., Ikemoto, K., Yoshida, K., and Shibuya, H. (2003). CYP2D6*10 alleles do not determine plasma fluvoxamine concentration/dose ratio in Japanese subjects. Eur. J. Clin. Pharmacol. 58, 659-661.
Okumura, T., Kishi, T., Okochi, T., Ikeda, M., Kitajima, T., Yamanouchi, Y., Kinoshita, Y., Kawashima, K., Tsunoka, T., Inada, T., Ozaki, N., and Iwata, N. (2010). Genetic association analysis of functional polymorphisms in neuronal nitric oxide synthase 1 gene (NOS1) and mood disorders and fluvoxamine response in major depressive disorder in the Japanese population. Neuropsychobiology 61, 57-63.

Overstreet, D., and Griebel, G. (2004). Antidepressant-like effects of CRF1 receptor antagonist SSR125543 in an animal model of depression. Eur. J. Pharmacol. 497, 49-53.

Owen, D., Du, L., Bakish, D., Lapierre, Y. D., and Hrdina, P. D. (1999). Norepinephrine transporter gene polymorphism is not associated with susceptibility to major depression. Psychiatry Res. 87, 1-5.

Paddock, S., Laje, G., Charney, D., Rush, A. J., Wilson, A. F., Sorant, A. J., Lipsky, R., Wisniewski, S. R., Manji, H., and McMahon, F. J. (2007). Association of GRIK4 with outcome of antidepressant treatment in the STAR*D cohort. Am. J. Psychiatry 164, 1181-1188.

Papiol, S., Arias, B., Gasto, C., Gutierrez, B., Catalan, R., and Fananas, L. (2007). Genetic variability at HPA axis in major depression and clinical response to antidepressant treatment. J. Affect. Disord. 104, 83-90.

Parsey, R. V., Olvet, D. M., Oquendo, M.A., Huang, Y.Y., Ogden, R. T., and Mann, J.J. (2006). Higher 5-HT1A receptor binding potential during a major depressive episode predicts poor treatment response: preliminary data from a naturalistic study.Neuropsychopharmacology 31, 1745-1749.

Paul, I. A. (2001). Antidepressant activity and calcium signaling cascades. Hum. Psychopharmacol. 16, 71-80.

Pavanello, S., Pulliero, A., Lupi, S., Gregorio, P., and Clonfero, E. (2005). Influence of the genetic polymorphism in the $5^{\prime}$-noncoding region of the CYP1A2 gene on CYP1A2 phenotype and urinary mutagenicity in smokers. Mutat. Res. 587, 59-66.

Perez, V., Gilaberte, I., Faries, D., Alvarez, E., and Artigas, F. (1997). Randomised, double-blind, placebo-controlled trial of pindolol in combination with fluoxetine antidepressant treatment. Lancet 349, 1594-1597.

Perlis, R. H. (2007). Pharmacogenetic studies of antidepressant response: how far from the clinic? Psychiatr. Clin. North Am. 30, 125-138.

Perlis, R. H., Fijal, B., Adams, D.H., Sutton, V. K., Trivedi, M. H., and Houston, J. P. (2009a). Variation in catechol-Omethyltransferase is associated with duloxetine response in a clinical trial for major depressive disorder. Biol. Psychiatry 65, 785-791.

Perlis, R. H., Laje, G., Smoller, J. W., Fava, M., Rush, A. J., and McMahon, F. J. (2009b). Genetic and clinical predictors of sexual dysfunction in citalopram-treated depressed patients. Neuropsychopharmacology 34, 1819-1828.

Perlis, R. H., Fijal, B., Dharia, S., Heinloth, A. N., and Houston, J.P. (2010). Failure to replicate genetic associations with antidepressant treatment response in duloxetine-treated patients. Biol. Psychiatry 67, 1110-1113.

Perlis, R. H., Purcell, S., Fagerness, J., Cusin, C., Yamaki, L., Fava, M., and Smoller, J. W. (2007a). Clinical and genetic dissection of anger expression and CREB1 polymorphisms in major depressive disorder. Biol. Psychiatry 62, 536-540.

Perlis, R. H., Purcell, S., Fava, M., Fagerness, J., Rush, A. J., Trivedi, M.H., and Smoller, J. W. (2007b). Association between treatment-emergent suicidal ideation with citalopram and polymorphisms near cyclic adenosine monophosphate response element binding protein in the STAR $* \mathrm{D}$ study. Arch. Gen. Psychiatry 64, 689-697.

Perroud, N.,Aitchison, K. J., Uher, R., Smith, R., Huezo-Diaz, P., Marusic, A., Maier, W., Mors, O., Placentino,A., Henigsberg, N., Rietschel, M., Hauser, J., Souery, D., Kapelski, P., Bonvicini, C., Zobel, A., Jorgensen, L., Petrovic, A., Kalember, P., Schulze, T. G., Gupta, B., Gray, J., Lewis, C. M., Farmer, A. E., McGuffin, P., and Craig, I. (2009). Genetic predictors of increase in suicidal ideation during antidepressant treatment in the GENDEP project. Neuropsychopharmacology 34, 2517-2528.

Perroud, N., Uher, R., Ng, M.Y., Guipponi, M., Hauser, J., Henigsberg, N., Maier, W., Mors, O., Gennarelli, M., Rietschel, M., Souery, D., Dernovsek, M. Z., Stamp, A. S., Lathrop, M., Farmer, A., Breen, G., Aitchison, K. J., Lewis, C. M., Craig, I. W., and McGuffin, P. (2010). Genome-wide association study of increasing suicidal ideation during antidepressant treatment in the GENDEP project. Pharmacogenomics J. doi: 10.1038/tpj.2010.70. [Epub ahead of print].

Peters, E. J., Slager, S. L., Jenkins, G. D., Reinalda, M. S., Garriock, H. A., Shyn, S. I., Kraft, J. B., McGrath, P. J., and Hamilton, S. P. (2009). Resequencing of serotonin-related genes and association of tagging SNPs to citalopram response. Pharmacogenet. Genomics 19, 1-10.

Peters, E. J., Slager, S. L., Kraft, J. B., Jenkins, G. D., Reinalda, M. S., McGrath, P. J., and Hamilton, S. P. (2008). Pharmacokinetic genes do not 
influence response or tolerance to citalopram in the STAR*D sample. PLoS ONE 3, e1872. doi: 10.1371/journal. pone.0001872

Peters, E. J., Slager, S. L., McGrath, P. J., Knowles, J. A., and Hamilton, S. P. (2004). Investigation of serotonin-related genes in antidepressant response. Mol. Psychiatry 9, 879-889.

Pollock, B. G., Ferrell, R. E., Mulsant, B. H., Mazumdar, S., Miller, M., Sweet, R. A., Davis, S., Kirshner, M. A., Houck, P. R., Stack, J. A., Reynolds, C. F., and Kupfer, D. J. (2000). Allelic variation in the serotonin transporter promoter affects onset of paroxetine treatment response in late-life depression. Neuropsychopharmacology 23, 587-590.

Prata, D. P., Mechelli, A., Picchioni, M.M., Fu, C. H., Toulopoulou, T., Bramon, E., Walshe, M., Murray, R. M., Collier, D. A., and McGuire, P. (2009). Altered effect of dopamine transporter $3^{\prime} \mathrm{UTR}$ VNTR genotype on prefrontal and striatal function in schizophrenia. Arch. Gen. Psychiatry 66, 1162-1172.

Raadsheer, F. C., Hoogendijk, W. J., Stam, F. C., Tilders, F. J., and Swaab, D. F. (1994). Increased numbers of corticotropin-releasing hormone expressing neurons in the hypothalamic paraventricular nucleus of depressed patients. Neuroendocrinology 60, 436-444.

Racagni, G., and Popoli, M. (2008). Cellular and molecular mechanisms in the long-term action of antidepressants. Dialogues Clin. Neurosci. 10, 385-400.

Rajewska-Rager, A., Skibinska, M., Szczepankiewicz, A., Kapelski, P., Dmitrzak-Weglarz, M., LeszczynskaRodziewicz, A., and Hauser, J. (2008). Association between polymorphisms of Val66Met in the BDNF gene and the response to escitalopram and nortriptyline treatment in the light of the neurodevelopmental hypothesis of depression. Psychiatr. Pol. 42, 915-923.

Rau, T., Wohlleben, G., Wuttke, H., Thuerauf, N., Lunkenheimer, J., Lanczik, M., and Eschenhagen, T. (2004). CYP2D6 genotype: impact on adverse effects and nonresponse during treatment with antidepressants-a pilot study. Clin. Pharmacol. Ther. 75, 386-393.

Rausch, J. L., Johnson, M. E., Fei, Y.-J., Li, J. Q., Shendarkar, N., Mac Hobby, H., Ganapathy, V., and Leibach, F. H. (2002). Initial conditions of serotonin transporter kinetics and genotype: influence on ssri treatment trial outcome. Biol. Psychiatry 51, 723-732.

Reagan, L.P., Hendry, R. M., Reznikov,L. R., Piroli, G. G., Wood, G. E., McEwen, B. S., and Grillo, C.A. (2007). Tianeptine increases brain-derived neurotrophic factor expression in the rat amygdala. Eur. J. Pharmacol. 565, 68-75.

Reimherr, F., Amsterdam, J., Dunner, D., Adler, L., Zhang, S., Williams, D., Marchant, B., Michelson, D., Nierenberg, A., Schatzberg, A., and Feldman, P. (2010). Genetic polymorphisms in the treatment of depression: speculations from an augmentation study using atomoxetine. Psychiatry Res. 175, 67-73.

Roberts, R. L., Joyce, P. R., Mulder, R. T, Begg, E. J., and Kennedy, M. A. (2002). A common P-glycoprotein polymorphism is associated with nortriptyline-induced postural hypotension in patients treated for major depression. Pharmacogenomics J. 2, 191-196.

Rochat, B., Baumann, P., and Audus, K. L. (1999). Transport mechanisms for the antidepressant citalopram in brain microvessel endothelium. Brain Res. 831, 229-236.

Rogoz, Z., Skuza, G., and Legutko, B. (2007). Repeated co-treatment with imipramine and amantadine induces hippocampal brain-derived neurotrophic factor gene expression in rats. J. Physiol. Pharmacol. 58, 219-234.

Rudberg, I., Mohebi, B., Hermann, M., Refsum, H., and Molden, E. (2008). Impact of the ultrarapid CYP2C19* 17 allele on serum concentration of escitalopram in psychiatric patients. Clin. Pharmacol. Ther. 83, 322-327.

Rujescu, D., Giegling, I., Sato, T., Hartmann, A., and Moller, H. (2003). Genetic variations in tryptophan hydroxylase in suicidal behavior: analysis and meta-analysis. Biol. Psychiatry $54,465-473$.

Rush, A. J., Trivedi, M. H., Wisniewski, S. R., Nierenberg, A. A., Stewart, J. W., Warden, D., Niederehe, G., Thase, M. E., Lavori, P. W., Lebowitz, B. D., McGrath, P. J., Rosenbaum, J. F., Sackeim, H. A., Kupfer, D. J., Luther, J., and Fava, M. (2006a). Acute and longer-term outcomes in depressed outpatients requiring one or several treatment steps: a STAR $* \mathrm{D}$ report. Am. J. Psychiatry 163, 1905-1917.

Rush, A. J., Trivedi, M. H., Wisniewski, S. R., Stewart, J. W., Nierenberg, A. A., Thase, M. E., Ritz, L., Biggs, M. M., Warden, D., Luther, J. F., ShoresWilson, K., Niederehe, G., and Fava, M. (2006b). Bupropion-SR, sertraline, or venlafaxine-XR after failure of SSRIs for depression. N. Engl. J. Med. 354, 1231-1242.

Sabol, S. Z., Hu, S., and Hamer, D. (1998). A functional polymorphism in the monoamine oxidase A gene promoter. Hum. Genet. 103, 273-279.

Sachse, C., Brockmoller, J., Bauer, S., and Roots, I. (1999). Functional significance of a $\mathrm{C} \rightarrow$ A polymorphism in intron 1 of the cytochrome P450
CYP1A2 gene tested with caffeine. $B r$. J. Clin. Pharmacol. 47, 445-449.

Samochowiec, J., Kucharska-Mazur, J., Kaminski, R., Smolka, M., Rommelschpacher, H., Wernicke, C., Tymicz, A., and Schmidt, L. G. (2002). Norepinephrine transporter gene polymorphism is not associated with susceptibility to alcohol dependence. Psychiatry Res. 111, 229-233.

Sano, A., Kondoh, K., Kakimoto, Y., and Kondo, I. (1993). A 40-nucleotide repeat polymorphism in the human dopamine transporter gene. Hum. Genet. 91, 405-406.

Sato, K., Yoshida, K., Takahashi, H., Ito, K., Kamata, M., Higuchi, H., Shimizu, T., Itoh, K., Inoue, K., Tezuka, T., Suzuki, T., Ohkubo, T., Sugawara, K., and Otani, K. (2002). Association between $-1438 \mathrm{G} / \mathrm{A}$ promoter polymorphism in the $5-\mathrm{HT}(2 \mathrm{~A})$ receptor gene and fluvoxamine response in Japanese patients with major depressive disorder. Neuropsychobiology 46, 136-140.

Schenk, P. W., van Vliet, M., Mathot, R. A., van Gelder, T., Vulto, A. G., van Fessem, M. A., Verploegh-Van Rij, S., Lindemans, J., Bruijn, J. A., and van Schaik, R.H.(2010). The CYP2C19*17 genotype is associated with lower imipramine plasma concentrations in a large group of depressed patients. Pharmacogenomics J. 10, 219-225.

Schinkel, A. H., Smit, J. J., van Tellingen, O., Beijnen, J. H., Wagenaar, E., van Deemter, L., Mol, C. A., van der Valk, M. A., Robanus-Maandag, E. C., and Riele, H. P. (1994). Disruption of the mouse mdrla P-glycoprotein gene leads to a deficiency in the bloodbrain barrier and to increased sensitivity to drugs. Cell 77, 491-502.

Schule, C., Baghai, T. C., Eser, D., and Rupprecht, R. (2009). Hypothalamicpituitary-adrenocortical system dysregulation and new treatment strategies in depression. Expert Rev. Neurother. 9, 1005-1019.

Secher, A., Bukh, J., Bock, C., Koefoed, P., Rasmussen, H. B., Werge, T., Kessing, L.V., and Mellerup, E. (2009). Antidepressive-drug-induced bodyweight gain is associated with polymorphisms in genes coding for COMT and TPH1. Int. Clin. Psychopharmacol. 24, 199-203.

Serretti, A., Artioli, P., Lorenzi, C., Pirovano, A., Tubazio, V., and Zanardi, R. (2004a). The C (-1019)G polymorphism of the 5-HT1A gene promoter and antidepressant response in mood disorders: preliminary findings. Int. J. Neuropsychopharmacol. 7, 453-460.

Serretti, A., Artioli, P.,Zanardi, R., Lorenzi, C., Rossini, D., Cusin, C., Arnoldi, A., and Catalano, M. (2004b). Genetic features of antidepressant induced mania and hypo-mania in bipolar disorder. Psychopharmacology (Berl.) 174, 504-511.

Serretti, A., Cusin, C., Rossini, D., Artioli, P., Dotoli, D., and Zanardi, R. (2004c). Further evidence of a combined effect of SERTPR and TPH on SSRIs response in mood disorders. Am. J. Med. Genet. B Neuropsychiatr. Genet. 129B, 36-40.

Serretti, A., Artioli, P., and Quartesan, R. (2005a). Pharmacogenetics in the treatment of depression: pharmacodynamic studies. Pharmacogenet. Genomics 15, 61-67.

Serretti, A., Cusin, C., Benedetti, F., Mandelli, L., Pirovano, A., Zanardi, R., Colombo, C., and Smeraldi, E. (2005b). Insomnia improvement during antidepressant treatment and CLOCK gene polymorphism. Am. J. Med. Genet. B Neuropsychiatr. Genet. 137B, 36-39.

Serretti, A., Benedetti, F., Colombo, C., Lilli, R., Lorenzi, C., and Smeraldi, E. (1999). Dopamine receptor D4 is not associated with antidepressant activity of sleep deprivation. Psychiatry Res. 89, 107-114.

Serretti, A., Benedetti, F., Mandelli, L., Lorenzi, C., Pirovano, A., Colombo, C., and Smeraldi, E. (2003a). Genetic dissection of psychopathological symptoms: insomnia in mood disorders and CLOCK gene polymorphism. Am. J. Med. Genet. B Neuropsychiatr. Genet. 121B, 39-43.

Serretti, A., Lorenzi, C., Cusin, C., Zanardi, R., Lattuada, E., Rossini, D., Lilli, R., Pirovano, A., Catalano, M., and Smeraldi,E. (2003b). SSRIs antidepressant activity is influenced by Gbeta3 variants. Eur. Neuropsychopharmacol. 13, 117-122.

Serretti, A., Calati, R., Mandelli, L., and De Ronchi, D. (2006). Serotonin transporter gene variants and behavior: a comprehensive review. Curr. Drug Targets 7, 1659-1669.

Serretti, A., Calati, R., Massat, I., Linotte, S., Kasper, S., Lecrubier, Y., Sens-Espel, R., Bollen, J., Zohar, J., Berlo, J., Lienard, P., De Ronchi, D., Mendlewicz, J., and Souery, D. (2009). Cytochrome P450 CYP1A2, CYP2C9, CYP2C19 and CYP2D6 genes are not associated with response and remission in a sample of depressive patients. Int Clin. Psychopharmacol. 24, 250-256.

Serretti, A., Chiesa, A., Calati, R., Massat, I., Linotte, S., Kasper, S., Lecrubier, Y., Antonijevic, I., Forray, C., Snyder, L., Bollen, J., Zohar, J., De Ronchi, D., Souery, D., and Mendlewicz, J. (2011). A preliminary investigation of the influence of CREB1 gene on treatment resistance in major depression. J. Affect. Disord. 128, 56-63.

Serretti, A., Drago, A., and De Ronchi, D. (2007a). HTR2A gene variants and 
psychiatric disorders: a review of current literature and selection of SNPs for future studies. Curr. Med. Chem. 14, 2053-2069.

Serretti, A., Kato, M., De Ronchi, D., and Kinoshita, T. (2007b). Meta-analysis of serotonin transporter gene promoter polymorphism (5-HTTLPR) association with selective serotonin reuptake inhibitor efficacy in depressed patients. Mol. Psychiatry 12, 247-257.

Serretti, A., Zanardi, R., Cusin, C., Rossini, D., Lilli, R., Lorenzi, C., Lattuada, E., and Smeraldi, E. (2001a). No association between dopamine D2 and D4 receptor gene variants and antidepressant activity of two selective serotonin reuptake inhibitors. Psychiatry Res. 104, 195-203.

Serretti, A., Zanardi, R., Cusin, C., Rossini, D.,Lorenzi,C., andSmeraldi,E.(2001b). Tryptophan hydroxylase gene associated with paroxetine antidepressant activity. Eur. Neuropsychopharmacol. $11,375-380$.

Serretti, A., Zanardi, R., Rossini, D., Cusin, C., Lilli, R., and Smeraldi, E. (2001c). Influence of tryptophan hydroxylase and serotonin transporter genes on fluvoxamine antidepressant activity. Mol. Psychiatry 6, 586-592.,

Seymour, P., Schmidt, A., and Schulz, D. (2003). The pharmacology of CP-154,526, a non-peptide antagonist of the CRH1 receptor: a review. CNS Drug Rev. 9, 57-96.

Shams, M. E., Arneth, B., Hiemke, C., Dragicevic, A., Muller, M. J., Kaiser, R., Lackner, K., and Hartter, S. (2006). CYP2D6 polymorphism and clinical effect of the antidepressant venlafaxine. J. Clin. Pharm. Ther. 31, 493-502.

Sharp, T., Boothman, L., Raley, J., and Queree, P. (2007). Important messages in the 'post': recent discoveries in 5-HT neurone feedback control. Trends Pharmacol. Sci. 28, 629-636.

Skrebuhhova, T., Allikmets, L., and Matto, V. (1999). Effects of anxiogenic drugs in rat forced swimming test. Methods Find Exp. Clin. Pharmacol. 21, 173-178.

Smeraldi, E., Serretti, A., Artioli, P., Lorenzi, C., and Catalano, M. (2006). Serotonin transporter gene-linked polymorphic region: possible pharmacogenetic implications of rare variants. Psychiatr. Genet. 16, 153-158.

Smeraldi, E., Zanardi, R., Benedetti, F., Dibella, D., Perez, J., and Catalano, M. (1998). Polymorphism within the promoter of the serotonin transporter gene and antidepressant efficacy of fluvoxamine. Mol. Psychiatry 3, 508-511.

Smith, D. A., Abel, S. M., Hyland, R., and Jones, B. C. (1998a). Human cytochrome P450s: selectivity and measurement in vivo. Xenobiotica 28, 1095-1128.

Smith, G., Stubbins, M. J., Harries, L. W., and Wolf, C. R. (1998b). Molecular genetics of the human cytochrome P450 monooxygenase superfamily. Xenobiotica 28, 1129-1165.

Smith, T. D., Kuczenski, R., GeorgeFriedman, K., Malley, J. D., and Foote, S. L. (2000). In vivo microdialysis assessment of extracellular serotonin and dopamine levels in awake monkeys during sustained fluoxetine administration. Synapse 38, 460-470.

Spina, E., Santoro, V., and D'Arrigo, C. (2008). Clinically relevant pharmacokinetic drug interactions with second-generation antidepressants: an update. Clin. Ther. 30, 1206-1227.

Sprouse, J.S., and Aghajanian, G.K. (1986). (-)-Propranolol blocks the inhibition of serotonergic dorsal raphe cell firing by 5 -HT1A selective agonists. Eur. J. Pharmacol. 128, 295-298.

Spurlock, G., Heils, A., Holmans, P., Williams, J., D’Souza, U. M., Cardno, A., Murphy, K. C., Jones, L., Buckland, P. R., McGuffin, P., Lesch, K. P., and Owen, M. J. (1998). A family based association study of T102C polymorphism in 5HT2A and schizophrenia plus identification of new polymorphisms in the promoter. Mol. Psychiatry 3, 42-49.

Stahl, S. M. (1998). Basic psychopharmacology of antidepressants, part 1: antidepressants have seven distinct mechanisms of action. J. Clin. Psychiatry 59(Suppl. 4), 5-14.

Steimer, W., Zopf, K., von Amelunxen, S., Pfeiffer, H., Bachofer, J., Popp, J., Messner, B., Kissling, W., and Leucht, S. (2004). Allele-specific change of concentration and functional gene dose for the prediction of steady-state serum concentrations of amitriptyline and nortriptyline in CYP2C19 and CYP2D6 extensive and intermediate metabolizers. Clin. Chem. 50, 1623-1633.

Sugai, T., Suzuki, Y., Sawamura, K., Fukui, N., Inoue, Y., and Someya, T. (2006). The effect of 5-hydroxytryptamine $3 \mathrm{~A}$ and $3 \mathrm{~B}$ receptor genes on nausea induced by paroxetine. Pharmacogenomics J. 6, 351-356.

Sulser, F. (2002). The role of CREB and other transcription factors in the pharmacotherapy and etiology of depression. Ann. Med. 34, 348-356.

Suzuki, E., Nakaki, T., Kanba, S., Shintani, F., and Miyaoka, H. (2003). Longterm imipramine treatment increases nitrate levels in the rat hypothalamus. Cell. Mol. Neurobiol. 23, 953-962.

Suzuki, Y., Sawamura, K., and Someya, T. (2004). The effects of a 5-hydroxytryptamine $1 \mathrm{~A}$ receptor gene polymorphism on the clinical response to fluvoxamine in depressed patients. Pharmacoecon. J. 4, 283-286.

Suzuki, Y., Sawamura, K., and Someya, T. (2006). Polymorphisms in the 5-hydroxytryptamine $2 \mathrm{~A}$ receptor and CytochromeP4502D6 genes synergistically predict fluvoxamine-induced side effects in Japanese depressed patients. Neuropsychopharmacology $31,825-831$.

Suzuki, Y., Sugai, T., Fukui, N., Watanabe, J., Ono, S., Inoue, Y., Ozdemir, V., and Someya, T. (2010). CYP2D6 genotype and smoking influence fluvoxamine steady-state concentration in Japanese psychiatric patients: lessons for genotype-phenotype association study design in translational pharmacogenetics. J. Psychopharmacol. doi: 10.1177/0269881110370504. [Epub ahead of print].

Svenningsson, P., Tzavara, E. T., Qi, H., Carruthers, R., Witkin, J. M., Nomikos, G. G., and Greengard, P. (2007). Biochemical and behavioral evidence for antidepressant-like effects of 5-HT6 receptor stimulation. J. Neurosci. 27, 4201-4209.

Szegedi, A., Rujescu, D., Tadic, A., Muller, M. J., Kohnen, R., Stassen, H. H., and Dahmen, N. (2005). The catecholO-methyltransferase Val108/158Met polymorphism affects short-term treatment response to mirtazapine, but not to paroxetine in major depression. Pharmacogenomics J. 5, 49-53.

Tadic, A., Muller, M. J., Rujescu, D., Kohnen, R., Stassen, H. H., Dahmen, N., and Szegedi, A. (2007). The MAOA T941G polymorphism and short-term treatment response to mirtazapine and paroxetine in major depression. Am. J. Med. Genet. B Neuropsychiatr. Genet. 144B, 325-331.

Tadic, A., Rujescu, D., Muller, M. J., Kohnen, R., Stassen, H. H., Szegedi, A., and Dahmen, N. (2008). Association analysis between variants of the interleukin-1beta and the interleukin-1 receptor antagonist gene and antidepressant treatment response in major depression. Neuropsychiatr. Dis. Treat. 4, 269-276.

Tanaka, M., Kobayashi, D., Murakami, Y., Ozaki, N., Suzuki, T., Iwata, N., Haraguchi, K., Ieiri, I., Kinukawa, N., Hosoi, M., Ohtani, H., Sawada, Y., and Mine, K. (2008). Genetic polymorphisms in the 5-hydroxytryptamine type $3 \mathrm{~B}$ receptor gene and paroxetine-induced nausea. Int. J. Neuropsychopharmacol. 11, 261-267.

Tardito, D., Perez, J., Tiraboschi, E., Musazzi, L., Racagni, G., and Popoli, M. (2006). Signaling pathways regulating gene expression, neuroplasticity, and neurotrophic mechanisms in the action of antidepressants: a critical overview. Pharmacol. Rev. 58, 115-134.

Taylor, M. J., Sen, S., and Bhagwagar, Z. (2010). Antidepressant response and the serotonin transporter gene-linked polymorphic region. Biol. Psychiatry $68,536-543$.

Thome, J., Sakai, N., Shin, K., Steffen, C., Zhang, Y. J., Impey, S., Storm, D., and Duman, R. S. (2000). cAMP response element-mediated gene transcription is upregulated by chronic antidepressant treatment. J. Neurosci. 20, 4030-4036.

Tremblay, P. B., Kaiser, R., Sezer, O., Rosler, N., Schelenz, C., Possinger, K., Roots, I., and Brockmoller, J. (2003). Variations in the 5-hydroxytryptamine type $3 \mathrm{~B}$ receptor gene as predictors of the efficacy of antiemetic treatment in cancer patients. J. Clin. Oncol. 21, 2147-2155.

Trivedi, M.H., Fava, M., Wisniewski, S. R., Thase, M. E., Quitkin, F., Warden, D., Ritz, L., Nierenberg, A.A., Lebowitz, B. D., Biggs, M. M., Luther, J. F., ShoresWilson, K., and Rush, A. J. (2006a). Medication augmentation after the failure of SSRIs for depression. $N$. Engl. J. Med. 354, 1243-1252.

Trivedi, M. H., Rush, A. J., Wisniewski, S. R., Nierenberg, A. A., Warden, D., Ritz, L., Norquist, G., Howland, R. H., Lebowitz, B., McGrath, P. J., Shores-Wilson, K., Biggs, M. M., Balasubramani, G. K., and Fava, M. (2006b). Evaluation of outcomes with citalopram for depression using measurement-based care in $\mathrm{STAR}^{\star} \mathrm{D}$ : implications for clinical practice. Am. J. Psychiatry 163, 28-40.

Tsai, M. H., Lin, K. M., Hsiao, M. C., Shen, W. W., Lu, M. L., Tang, H. S., Fang, C. K., Wu, C. S., Lu, S. C., Liu, S. C., Chen, C. Y., and Liu, Y. L. (2010). Genetic polymorphisms of cytochrome $\mathrm{P} 450$ enzymes influence metabolism of the antidepressant escitalopram and treatment response. Pharmacogenomics 11, 537-546.

Tsai, S. J., Cheng, C. Y., Yu, Y. W., Chen, T. J., and Hong, C. J. (2003). Association study of a brain-derived neurotrophic-factor genetic polymorphism and major depressive disorders, symptomatology, and antidepressant response. Am. J. Med. Genet. B Neuropsychiatr. Genet. 123B, 19-22.

Tsai, S. J., Gau, Y. T., Hong, C. J., Liou, Y. J., Yu, Y. W., and Chen, T. J. (2009a). Sexually dimorphic effect of catechol-O-methyltransferase val158met polymorphism on clinical response to fluoxetine in major depressive patients. J. Affect. Disord. 113, 183-187.

Tsai, S. J., Hong, C. J., Liou, Y. J., Yu, Y. W., Chen, T. J., Hou, S. J., and Yen, F. C. (2009b). Tryptophan hydroxylase 2 gene is associated 
with major depression and antidepressant treatment response. Prog. Neuropsychopharmacol. Biol. Psychiatry 33, 637-641.

Tsunoka, T., Kishi, T., Ikeda, M., Kitajima, T., Yamanouchi, Y., Kinoshita, Y., Kawashima, K., Okochi, T., Okumura, T., Inada, T., Ozaki, N., and Iwata, N. (2009). Association analysis of group II metabotropic glutamate receptor genes (GRM2 and GRM3) with mood disorders and fluvoxamine response in a Japanese population. Prog. Neuropsychopharmacol. Biol. Psychiatry 33, 875-879.

Tzeng, D. S., Chien, C. C., Lung, F. W., and Yang, C. Y. (2009). MAOA gene polymorphisms and response to mirtazapine in major depression. Hum. Psychopharmacol. 24, 293-300.

Tzvetkov, M. V., Brockmoller, J., Roots, I., and Kirchheiner, J. (2008). Common genetic variations in human brainspecific tryptophan hydroxylase-2 and response to antidepressant treatment. Pharmacogenet. Genomics 18, 495-506.

Uher, R., Huezo-Diaz, P., Perroud, N., Smith, R., Rietschel, M., Mors, O., Hauser, J., Maier, W., Kozel, D., Henigsberg, N., Barreto,M.,Placentino, A., Dernovsek, M. Z., Schulze, T. G., Kalember, P., Zobel, A., Czerski, P. M., Larsen, E. R., Souery, D., Giovannini, C., Gray, J. M., Lewis, C. M., Farmer, A., Aitchison, K. J., McGuffin, P., and Craig, I. (2009). Genetic predictors of response to antidepressants in the GENDEP project. Pharmacogenomics J. 9, 225-233.

Uher, R., Perroud, N., Ng, M. Y., Hauser, J., Henigsberg, N., Maier, W., Mors, O., Placentino, A., Rietschel, M., Souery, D., Zagar, T., Czerski, P. M., Jerman, B., Larsen, E. R., Schulze, T. G., Zobel, A., Cohen-Woods, S., Pirlo, K., Butler, A. W., Muglia, P., Barnes, M. R., Lathrop, M., Farmer, A., Breen, G., Aitchison, K. J., Craig, I., Lewis, C. M., and McGuffin, P. (2010). Genome-wide pharmacogenetics of antidepressant response in the GENDEP project. Am. J. Psychiatry 167, 555-564.

Uhr, M., Steckler, T., Yassouridis, A., and Holsboer, F. (2000). Penetration of amitriptyline, but not of fluoxetine, into brain is enhanced in mice with blood-brain barrier deficiency due to mdrla P-glycoprotein gene disruption. Neuropsychopharmacology 22, 380-387.

Van Asperen, J., Van Tellingen, O., and Beijnen, J. H. (1998). The pharmacological role of P-glycoprotein in the intestinal epithelium. Pharmacol. Res. 37, 429-435.

Van Pett, K., Viau, V., Bittencourt, J. C., Chan, R. K., Li, H. Y., Arias, C., Prins, G. S., Perrin, M., Vale, W., and Sawchenko,
P. E. (2000). Distribution of mRNAs encoding CRF receptors in brain and pituitary of rat and mouse. J. Comp. Neurol. 428, 191-212.

van Rossum, E. F., Binder, E. B., Majer, M., Koper, J. W., Ising, M., Modell, S., Salyakina, D., Lamberts, S. W., and Holsboer, F. (2006). Polymorphisms of the glucocorticoid receptor gene and major depression. Biol. Psychiatry 59, 681-688.

Vaquero-Lorenzo, C., Baca-Garcia, E., Diaz-Hernandez, M., PerezRodriguez,M.M., Fernandez-Navarro, P., Giner, L., Carballo, J. J., Saiz-Ruiz, J., Fernandez-Piqueras, J., Baldomero, E. B., de Leon, J., and Oquendo, M. A. (2008). Association study of two polymorphisms of the serotonin- $2 \mathrm{~A}$ receptor gene and suicide attempts. Am. J. Med. Genet. B Neuropsychiatr. Genet. 147B, 645-649.

Verge, D., Daval, G., Patey, A., Gozlan, H., el Mestikawy, S., and Hamon, M. (1985). Presynaptic 5-HT autoreceptors on serotonergic cell bodies and/or dendrites but not terminals are of the 5-HT1A subtype. Eur. J. Pharmacol. 113, 463-464.

Viikki, M., Kampman, O., Illi, A., SetalaSoikkeli, E., Anttila, S., Huuhka, M., Nuolivirta, T., Poutanen, O., Mononen, N., Lehtimaki, T., and Leinonen, E. (2010). TPH1 218A/C polymorphism is associated with major depressive disorder and its treatment response. Neurosci. Lett. 468, 80-84.

Villafuerte, S. M., Vallabhaneni, K., Sliwerska, E., McMahon, F. J., Young, E. A., and Burmeister, M. (2009). SSRI response in depression may be influenced by SNPs in HTR1B and HTR1A. Psychiatr. Genet. 19, 281-291.

Waldman, I. D., Robinson, B. F., and Feigon, S. A. (1997). Linkage disequilibrium between the dopamine transporter gene (DAT1) and bipolar disorder: extending the transmission disequilibrium test (TDT) to examine genetic heterogeneity. Genet. Epidemiol. 14, 699-704.

Wang, R. Y., and Aghajanian, G. K. (1977). Inhibition of neurons in the amygdala by dorsal raphe stimulation: mediation through a direct serotonergic pathway. Brain Res. 120, 85-102.

Wegener, G., Volke, V., Harvey, B. H., and Rosenberg, R. (2003). Local, but not systemic, administration of serotonergic antidepressants decreases hippocampal nitric oxide synthase activity. Brain Res. 959, 128-134.

Wesolowska, A., and Nikiforuk, A. (2007). Effects of the brain-penetrant and selective 5-HT6 receptor antagonist SB-399885 in animal models of anxiety and depression. Neuropharmacology 52, 1274-1283.
Wilkie,M.J.,Smith,D., Reid,I.C., Day, R.K., Matthews, K., Wolf, C. R., Blackwood, D., and Smith, G. (2007). A splice site polymorphism in the G-protein beta subunit influences antidepressant efficacy in depression. Pharmacogenet. Genomics 17, 207-215.

Wilkie, M. J., Smith, G., Day, R. K., Matthews, K., Smith, D., Blackwood, D., Reid, I. C., and Wolf, C. R. (2009). Polymorphisms in the SLC6A4 and HTR2A genes influence treatment outcome following antidepressant therapy. Pharmacogenomics J. 9, 61-70.

Williams, J., Spurlock, G., McGuffin, P., Mallet, J., Nothen, M. M., Gill, M., Aschauer, H., Nylander, P. O., Macciardi, F., and Owen, M. J. (1996). Association between schizophrenia and $\mathrm{T} 102 \mathrm{C}$ polymorphism of the 5 -hydroxytryptamine type $2 \mathrm{a}$-receptor gene. European Multicentre Association Study of Schizophrenia (EMASS) Group. Lancet 347, 1294-1296.

Willner, P., Hale, A. S., and Argyropoulos, S. (2005). Dopaminergic mechanism of antidepressant action in depressed patients. J. Affect. Disord. 86, 37-45.

Wu, W. H., Huo, S. J., Cheng, C. Y., Hong, C. J., and Tsai, S. J. (2001). Association study of the 5-HT(6) receptor polymorphism (C267T) and symptomatology and antidepressant response in major depressive disorders. Neuropsychobiology $44,172-175$.

Yamada, K., Hattori, E., Iwayama, Y., Ohnishi, T., Ohba, H., Toyota, T., Takao, H., Minabe, Y., Nakatani, N., Higuchi, T., Detera-Wadleigh, S. D., and Yoshikawa, T. (2006). Distinguishable haplotype blocks in the HTR3A and HTR3B region in the Japanese reveal evidence of association of HTR3B with female major depression. Biol. Psychiatry 60, 192-201.

Yamauchi,M., Takako,M., Tetsuya,M., and Imanishi, T. (2005). Desensitization of 5-HT2A receptor function by chronic administration of selective serotonin reuptake inhibitors. Brain Res. 1067, 164-169.

Yang, L., Wang, Y. F., Li, J., and Faraone, S. V. (2004). Association of norepinephrine transporter gene with methylphenidate response. J. Am. Acad. Child Adolesc. Psychiatry 43, 1154-1158.

Yatham,L.N.,Liddle, P.F., Dennie, J.,Shiah, I. S., Adam, M. J., Lane, C. J., Lam, R. W., and Ruth, T. J. (1999). Decrease in brain serotonin 2 receptor binding in patients with major depression following desipramine treatment - a positron emission tomography study with fluorine-18-labeled setoperone. Arch. Gen. Psychiatry 56, 705-711.
Yin, O. Q., Wing, Y. K., Cheung, Y., Wang, Z. J., Lam, S. L., Chiu, H. F., and Chow, M. S. (2006). Phenotype-genotype relationship and clinical effects of citalopram in Chinese patients. J. Clin. Psychopharmacol. 26, 367-372.

Yoshida, K., Higuchi, H., Kamata, M., Takahashi, H., Inoue, K., Suzuki, T., Itoh, K., and Ozaki, N. (2007). The G196A polymorphism of the brain-derived neurotrophic factor gene and the antidepressant effect of milnacipran and fluvoxamine. $J$. Psychopharmacol. 21, 650-656.

Yoshida, K., Higuchi, H., Takahashi, H., Kamata, M., Sato, K., Inoue, K., Suzuki, T., Itoh, K., and Ozaki, N. (2008). Influence of the tyrosine hydroxylase val81met polymorphism and catechol-O-methyltransferase val158met polymorphism on the antidepressant effect of milnacipran. Hum. Psychopharmacol. 23, 121-128.

Yoshida, K., Naito, S., Takahashi, H., Sato, K., Ito, K., Kamata, M., Higuchi, H., Shimizu, T., Itoh, K., Inoue, K., Tezuka, T., Suzuki, T., Ohkubo, T., Sugawara, K., and Otani, K. (2002). Monoamine oxidase: a gene polymorphism, tryptophan hydroxylase gene polymorphism and antidepressant response to fluvoxamine in Japanese patients with major depressive disorder. Prog. Neuropsychopharmacol. Biol. Psychiatry 26, 1279-1283.

Yoshida, K., Takahashi, H., Higuchi, H., Kamata, M., Ito, K., Sato, K., Naito, S., Shimizu, T., Itoh, K., Inoue, K., Suzuki, T., and Nemeroff, C. B. (2004). Prediction of antidepressant response to milnacipran by norepinephrine transporter gene polymorphisms. Am. J. Psychiatry 161, 1575-1580.

Yu, Y. W., Chen, T. J., Hong, C. J., Chen, H. M., and Tsai, S. J. (2003). Association study of the interleukin-1beta (C-511T) genetic polymorphism with major depressive disorder, associated symptomatology, and antidepressant response. Neuropsychopharmacology 28, 1182-1185.

Yu, Y. W., Tsai, S. J., Liou, Y. J., Hong, C. J., and Chen, T. J. (2006). Association study of two serotonin 1A receptor gene polymorphisms and fluoxetine treatment response in Chinese major depressive disorders. Eur. Neuropsychopharmacol. 16, 498-503.

Zanardi, R., Benedetti, F., DiBella, D., Catalano, M., and Smeraldi, E. (2000). Efficacy of paroxetine in depression is influenced by a functional polymorphism within the promoter of serotonin transporter gene. J. Clin. Psychopharmacol. 20, 105-107.

Zanardi, R., Serretti, A., Rossini, D., Franchini, L., Cusin, C., Lattuada, E., Dotoli, D., and Smeraldi, E. (2001). 
Factors affecting fluvoxamine antidepressant activity: influence of pindolol and 5-HTTLPR in delusional and nondelusional depression. Biol. Psychiatry 50, 323-330.

Zhou, F. M., Liang, Y., Salas, R., Zhang, L., De Biasi, M., and Dani, J. A. (2005). Corelease of dopamine and serotonin from striatal dopamine terminals. Neuron 46, 65-74.

Zill, P., Baghai, T. C., Engel, R., Zwanzger, P., Schule, C., Minov, C., Behrens, S., Bottlender, R., Jager, M., Rupprecht, R., Moller, H. J., Ackenheil, M., and Bondy, B. (2003). Beta-1-adrenergic receptor gene in major depression: influence on antidepressant treatment response. Am. J. Med. Genet. B Neuropsychiatr. Genet. 120B, 85-89.

Zill, P., Baghai, T. C., Zwanzger, P., Schule, C., Minov, C., Riedel, M., Neumeier, K.,
Rupprecht, R., and Bondy, B. (2000). Evidence for an association between a G-protein beta3-gene variant with depression and response to antidepressant treatment. Neuroreport 11, 1893-1897.

Zill, P., Engel, R., Baghai, T. C., Juckel, G., Frodl, T., Muller-Siecheneder, F., Zwanzger, P., Schule, C., Minov, C., Behrens, S., Rupprecht, R., Hegerl, U., Moller, H. J., and Bondy, B. (2002). Identification of a naturally occurring polymorphism in the promoter region of the norepinephrine transporter and analysis in major depression. Neuropsychopharmacology 26, 489-493.

Zou, Y. F., Wang, Y., Liu, P., Feng, X. L., Wang, B. Y., Zang, T. H., Yu, X., Wei, J., Liu, Z. C., Liu, Y., Tao, M., Li, H. C., Li, K. Q., Hu, J., Li, M., Zhang, K. R., Ye, D.
Q., and Xu, X. P. (2010a). Association of brain-derived neurotrophic factor genetic Val66Met polymorphism with severity of depression, efficacy of fluoxetine and its side effects in Chinese major depressive patients. Neuropsychobiology 61, 71-78.

Zou, Y. F., Ye, D. Q., Feng, X. L., Su, H. Pan, F. M., and Liao, F. F. (2010b). Meta-analysis of BDNF Val66Met polymorphism association with treatment response in patients with major depressive disorder. Eur. Neuropsychopharmacol. 20, 535-544.

Conflict of Interest Statement: The authors declare that the research was conducted in the absence of any commercial or financial relationships that could be construed as a potential conflict of interest.
Received: 06 December 2010; paper pending published: 27 December 2010; accepted: 04 February 2011; published online: 16 February 2011.

Citation: Crisafulli C, Fabbri C, Porcelli S, Drago A, Spina E, De Ronchi D and Serretti A (2011) Pharmacogenetics of antidepressants. Front. Pharmacol. 2:6. doi: 10.3389/ fphar.2011.00006

This article was submitted to Frontiers in Pharmacogenetics and Pharmacogenomics, a specialty of Frontiers in Pharmacology. Copyright (c) 2011 Crisafulli, Fabbri, Porcelli, Drago, Spina, De Ronchi and Serretti. This is an open-access article subject to an exclusive license agreement between the authors and Frontiers Media $S A$, which permits unrestricted use, distribution, and reproduction in any medium, provided the original authors and source are credited. 